\title{
Groundwater Quality Assessment Plan for the Metallurgical Laboratory Hazardous Waste Management Facility (U)
}

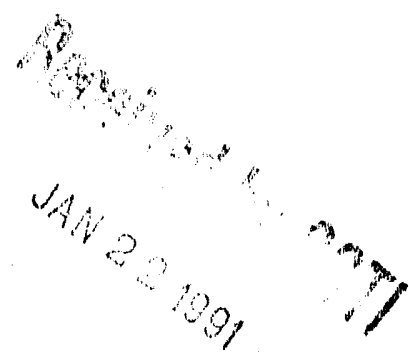

\section{DISCLAIMER}

This report was prepared as an account of work sponsored by an agency of the United States Government. Neither the United Siates Government nor any agency thereof, nor any of their employees, makes any warranty, express or implied, or assumes any legal liability or responsibility for the accuracy, completeness, or usefulness of any information, apparatus, product, or process disclosed, or represents that its use would not infringe privately owned rights. Reference herein to any specific commercial product, process, or service by trade name, trademark, manufacturer, or otherwise does not necessarily constitute or imply its endorsement, recommendation, or favoring by the United States Government or any agency thereof. The views and opinions of authors expressed herein do not necessarily state or reflect those of the United States Government or any agency thereof. 


\section{Groundwater Quality Assessment Plan} for the Metallurgical Laboratory Hazardous Waste Management Facility

October 1990

K. M. Jerome

Approved by: Depromes

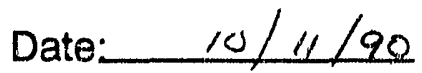

D. B. Moore, Manager Environmental Sciences Section Savannah River Laboratory

Keywords: Resource Conservation and Recovery Act, Assessments, Metallurgical Laboratory, Ground Water, Seepage Basins

WESTINGHOUSE SAVANNAH RIVER COMPANY SAVANNAH RIVER SITE AIKEN, SC 29808 
TABLE OF CONTENTS

INTRODUCTION

HISTORY OF THE FACILITY

DEFINITION OF THE UPPERMOST AQUIFER 4

LOCATION OF WELLS: Existing $\ldots \ldots \ldots \ldots \ldots \ldots \ldots \ldots \ldots$

LOCATION OF WELLS: Proposed $\ldots \ldots \ldots \ldots \ldots \ldots \ldots \ldots \ldots \ldots$

INSTALLATION OF WELLS $\ldots \ldots \ldots \ldots \ldots \ldots \ldots \ldots \ldots \ldots \ldots \ldots \ldots \ldots$

DEVELOPMENT OF WELLS $\ldots \ldots \ldots \ldots \ldots \ldots \ldots \ldots \ldots \ldots$

SAMPLING AND ANALYSIS $\ldots \ldots \ldots \ldots \ldots \ldots \ldots \ldots \ldots \ldots \ldots \ldots$

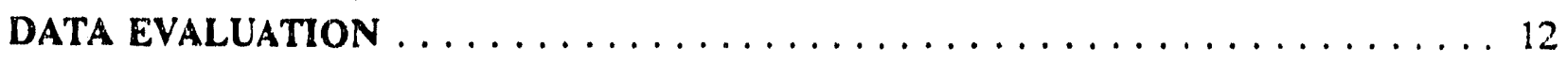

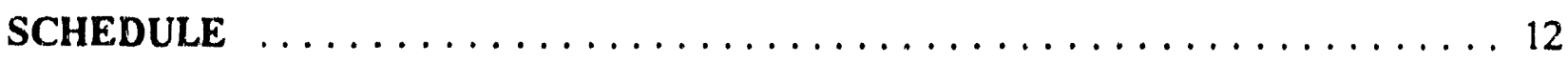

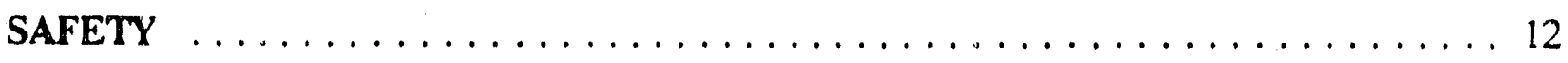

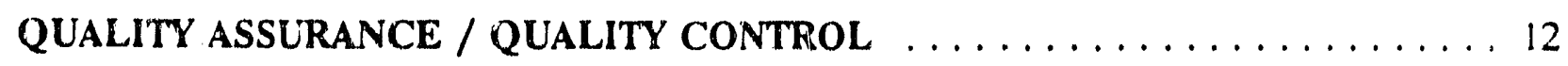

APPENDIX A TRENDS OF CONTAMINANTS FROM 4 Q88 TO $2090 \ldots \ldots$ A-1

APPENDIX B WELL CONSTRUCTION INFORMATION ........... B-1 


\section{LIST OF FIGURES}

Figure 1: Well log depicting location of Uppermost Aquifer $\ldots \ldots \ldots \ldots \ldots$

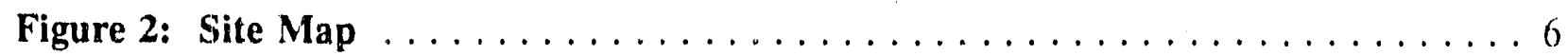

Figure 3: Water Table Potentiometric Map $1 Q 90 \ldots \ldots \ldots \ldots \ldots \ldots$

Figure 4: Upper Congaree Potentiometric Map 1 Q90 . . . . . . . . . . . 10

Figure 5: Lower Congaree Potentiometric Map $1090 \ldots \ldots \ldots \ldots \ldots \ldots \ldots \ldots$ 


\section{LIST OF TABLES}

Table 1: Summary of 2Q90 Metallurgical Laboratory Hazardous Waste Management

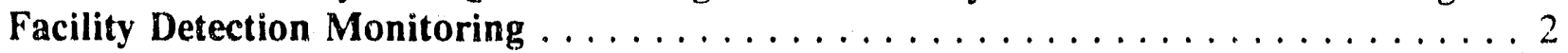

Table 2: Constituents analyzed for at the MLHWMF $\ldots \ldots \ldots \ldots \ldots \ldots$

Table 3: Information on existing and proposed well installations $\ldots \ldots \ldots \ldots$

Table 4: Indicator parameters for detection monitoring at the Metallurgical Laboratory Hazardous Waste Management Facility with their approved EPA Analytical Methods 1.3

Table 5: Schedule of Activities for the Metallurgical Laboratory HWMF Part B Permit Revision ................................ 15 


\section{INTRODUCTION}

The Metallurgical Laboratory Hazardous Waste Management Facility (MLHWMF) will be closed under interim status regulation (SCDHEC Regulations R.61-79.265) and permitted as a hazardous waste management facility by a Post Closure Part B Permit under 40 CFR 264. Both the closure and post closure of the MLHWMF under 40 CFR regulations were prescribed in the NRDC Consent Decree settlement which resulted from Docket \#CV AC 1:85-2583-6 in the UNITED STATES DISTRICT COURT, DISTRICT OF SOUTH CAROLINA, AIKEN DIVISION. A groundwater monitoring program for the MLHWMF is required under both interim status (Part A Facility) and permitted status (approved Part B Facility). The boundaries of the MLHWMF were determined by estimating the historical high water mark in the overflow area using historical areal photographs, existing site topographic maps, and existing vegetation changes.

\section{HISTORY OF THE FACILITY}

The Metallurgical Laboratory Hazardous Waste Management Facility consists of the process sewer line leading to the Metallurgicai Laboratory basin from the fence, the Metallurgical Laboratory basin, the drainage outfall to the Carolina bay, and the Carolina bay itself. The Metallurgical Laboratory basin was constructed in 1956. It received effluent consisting primarily of the noncontact cooling water and small quantities of laboratory rinsewater from the Metallurgisil Laboratory. The effluent was discharged continuously at approximately 1,000 gallons per day (gpd) throughout the operating period of the basin. The release of hazardous wastes to the Metallurgical Laboratory HWMF was discontinued in 1983. All flow to the Metallurgical Laboratory HWMF was terminated on November 8, 1985.

The Metallurgical Laboratory HWMF received F001, F003, F007, and D011 waste. F001 waste includes spent halogenated solvents used in degreasing (trichloroethylene, 1,1,1trichloroethane, and carbon tetrachloride). F003 waste includes spent nonhalogenated solvents (acetone), and F007 waste is spent cyanide plating bath solution. Extract from D001 waste obtained using the extraction procedure (EP) toxicity test contains silver in concentrations greater than $5 \mathrm{mg} / \mathrm{l}$.

At present forty-three constituents are analyzed per sample. Trichloroethylene, tetrachloroethylene, and total radium are the only constituents that were reported above Primary Drinking Water Standards (PDWS) during 2090 (Table 1). Table 2 lists the constituents that are being analyzed at present. Appendix A presents the trends for the analyzed constituents from $4 \mathrm{Q} 88$ to $2 \mathrm{Q} 90$. 


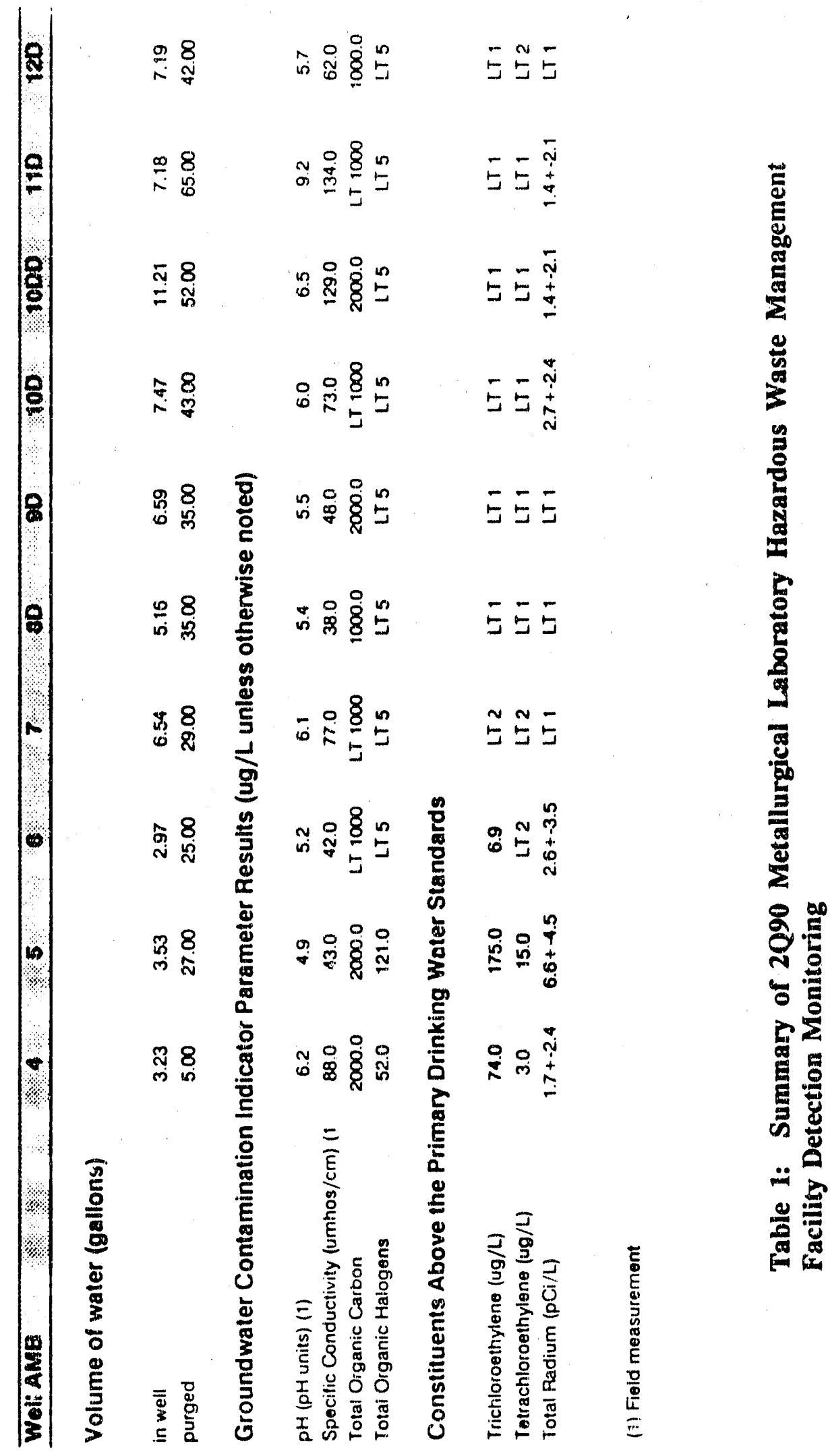


Table 2: Constituents analyzed for at the MLHWMF

Specific Conductance

$\mathrm{pH}$

Silver

Arsenic

Barium

Calcium

Carbon Tetrachloride

Cadmium

Chloroform

Chloride

Chromium

Cyanide

Endrin

Fluoride

Iron

Mercury

Potassium

Lindane

Methoxychlor

Magnesium

Manganese

Sodium

Nickel

Nitrate as Nitrogen

Lead

Phenols
Selenium

Silica

Silvex

Sulfate

Tetrachloroethylene

Total Dissolved Solids

Total Organic Carbon

Total Organic Halogens

Total Phosphates

Trichloroethylene

Toxaphene

Trans-1,2-dichloroethene

1,1-Dichloroethene

1,1,1-Trichloroethane

2,4-Dichlorophenoxyacetic Acid

Gross Alpha

Nonvolatile Beta

Total Radium

Tritium 


\section{DEFINITION OF THE UPPERMOST AQUYFER}

The uppermost aquifer in the vicinity of MLHWMF is considered to extend from the surface of the water table to the top of the Ellenton clay and is approximately 115 feet thick as depicted in Figure 1.

\section{LOCATION OF WELLS}

\section{Existing}

Currently there are 9 water table monitoring wells and 1 perched water table monitoring well (AMB 10DD) installed at the MLHWMF as shown on Figure 2. Table 3 lists the well identification number, location, and screen elevations for each of the exis ing wells. All of the existing monitoring wells were installed under DPSOP 254 specifications. Additional construction information for the existing wells is presented in Appendix B. Monitoring wells AMB 4D-6D, 8D, and 10D are downgradient wells; wells AMB 7D, 10D, and 12D are sidegradient wells; and 11D are upgradient wells. Water table elevations from the existing wells indicate that there is a very small horizontal gradient to the northwest at the facility. Figure 3 shows the water table surface in the vicinity of the MLHWMF for 1 Q90.

\section{Proposed}

Installation of monitoring wells around the MLHWMF area consists of 3 upper Congaree (B) wells and 3 lower Congaree (A) wells. No additional water table wells will be installed. Table 1 lists the well identification number, location, and approximate depth for each of the proposed weils. These wells will be located downgradient to flow in the respective unit. Monitoring wells $A M B 10 B$ and $13 B$ are proposed downgradient wells and $A M B$ B is the proposed upgradient well for the upper Congaree. Monitoring wells AMB 10A and 13A are the proposed downgradient wells and $\mathrm{AMB} 6 \mathrm{~A}$ is the proposed upgradient well for the lower Congaree.

The decision to not install additional water table wells was made based on the fact that there exist sufficient water table monitoring wells downgradient to provide sufficient data on plume movement in the water table zone. These wells were installed and are maintained as part of the SRS M-Area HWMF Corrective Action Plan (CAP). The purpose of these wells is to define the extent, concentration distribution, and migration rate of the solve.", plume. As part of an on-going groundwater quality program, these wells were used to provide a large hydrologic, geologic, and water-quality information data base in and around the A- and M-Area.

Following delineation of the contamination plume a comprehensive remedial action effort prepered by the SRS, submitted and approved by SCDHEC, was put into operation. As part of the remedial action program a continuing investigation of groundwater 
Figure 1: Well log depicting location of $U$ ppermost Aquifer

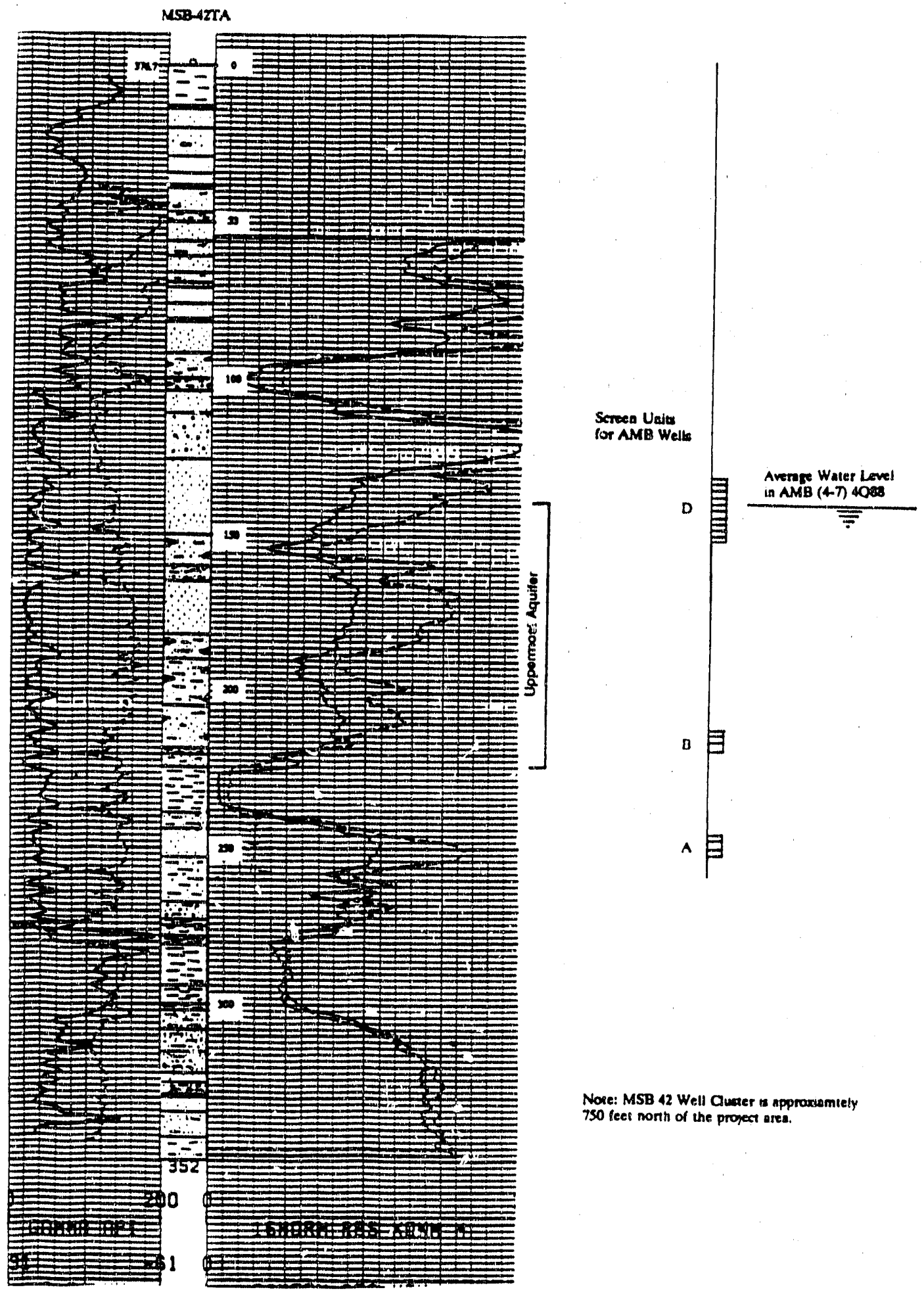


Figure 2: Site Map

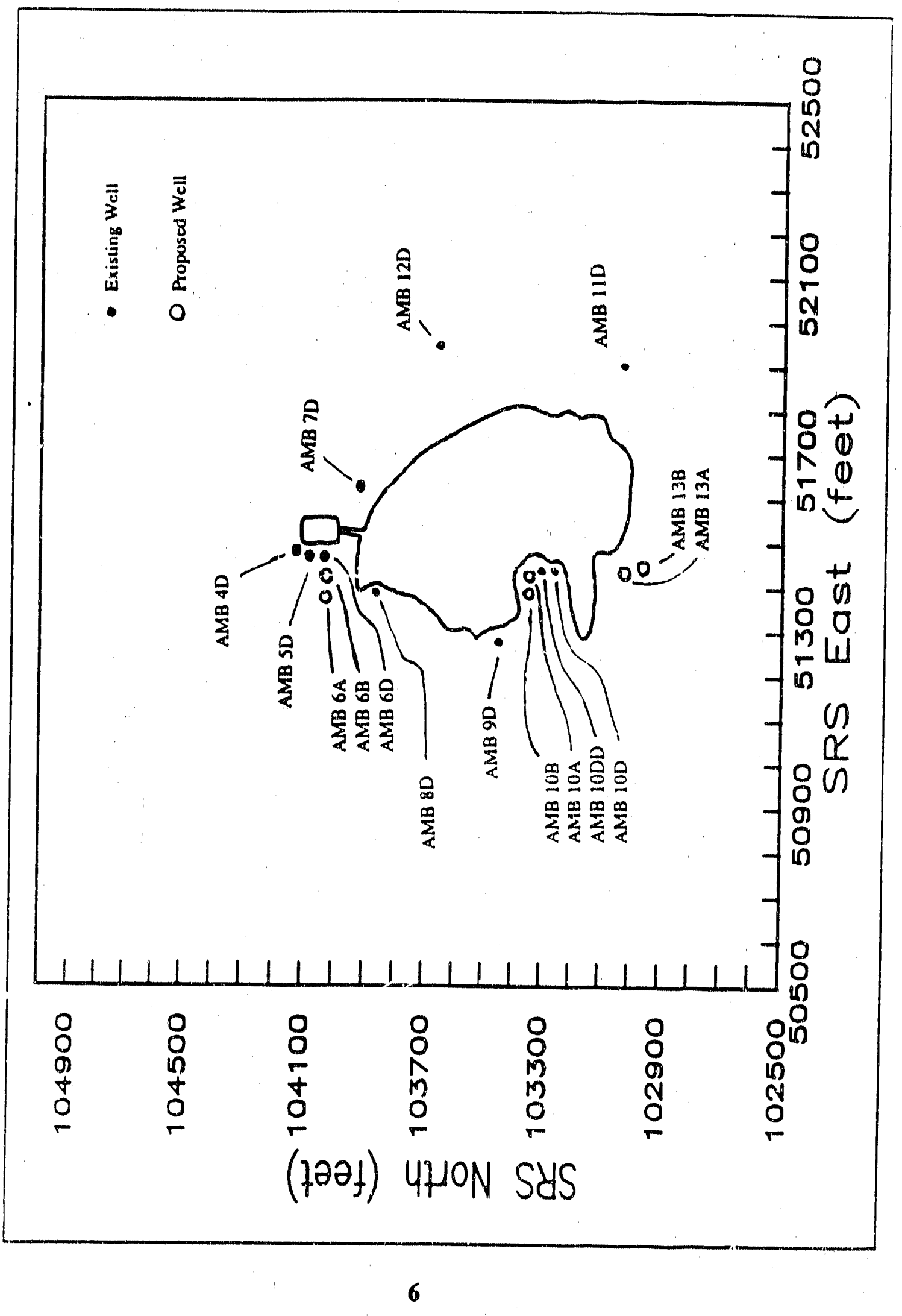


Figure 3: Water Table Potentiomerric Map 1 Q90

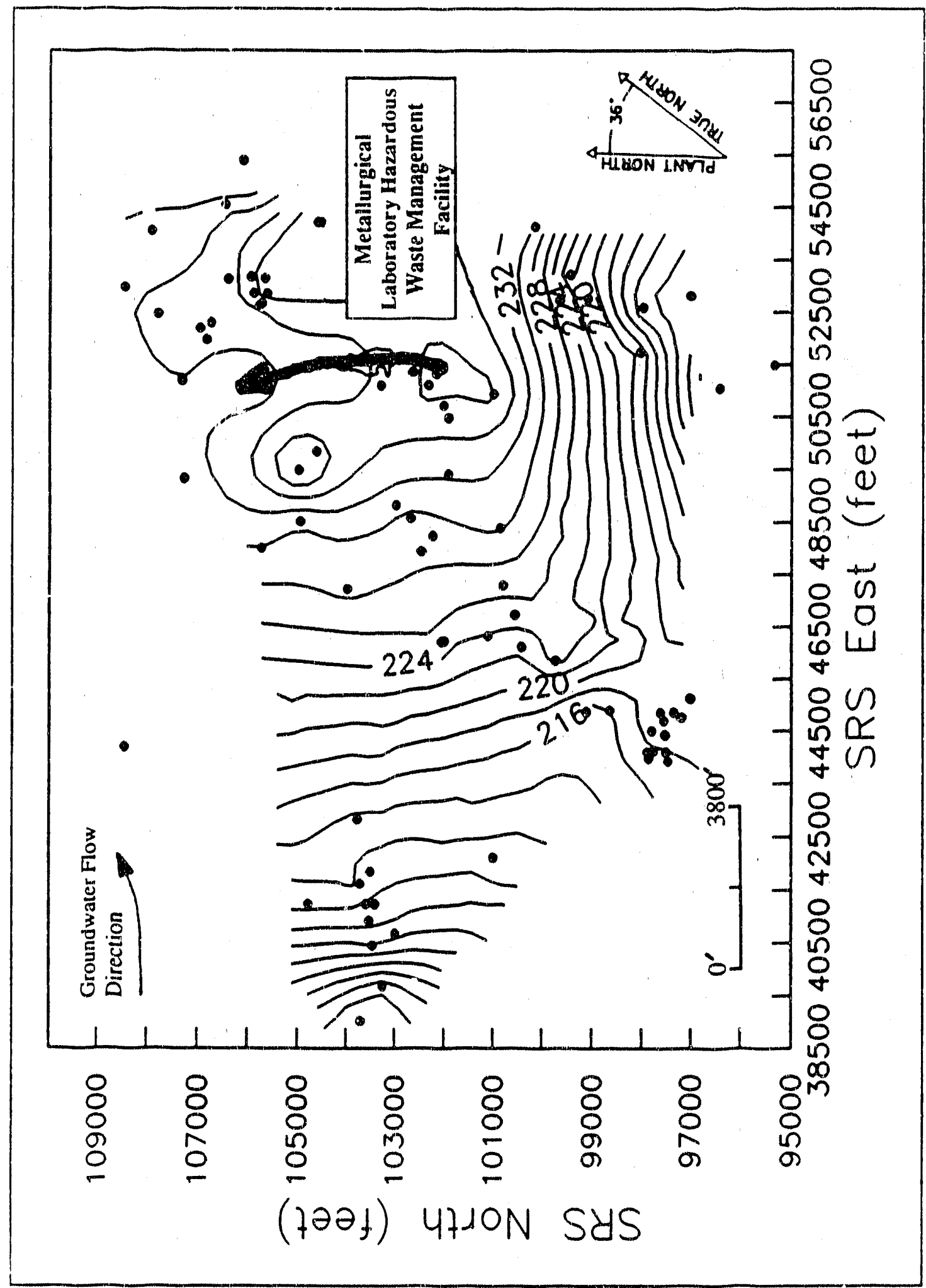


Table 3: Information on existing and proposed well installations

\begin{tabular}{|c|c|c|c|c|c|c|c|c|c|}
\hline \multirow[b]{2}{*}{ Well ID } & \multirow[b]{2}{*}{ Type } & \multirow[b]{2}{*}{$\begin{array}{l}\text { Crilling } \\
\text { Method }\end{array}$} & \multirow[b]{2}{*}{$\begin{array}{l}\text { Approximate } \\
\text { Depth (tt) }\end{array}$} & \multicolumn{2}{|c|}{$\begin{array}{l}\text { Screen Elevation } \\
(\mathrm{msl}, \mathrm{tt})\end{array}$} & \multicolumn{2}{|c|}{$\begin{array}{c}\text { SRP } \\
\text { Coondinates }\end{array}$} & \multirow[b]{2}{*}{ Laxttude } & \multirow[b]{2}{*}{ Lorngltude } \\
\hline & & & & Top & Bottom & Nonth & East & & \\
\hline \multicolumn{10}{|l|}{$\begin{array}{l}\text { Existing } \\
\text { Wrells }\end{array}$} \\
\hline$A M O 4 D$ & $D G$ & 2 & 165 & 242 & 222 & 104125 & 51480 & 33.3400434 & 81.7335490 \\
\hline AMB 5D & 03 & 2 & 165 & 242 & 222 & 104083 & 51467 & 33.3399293 & 81.7335016 \\
\hline AMB 60 & DG & $?$ & 165 & 245 & 225 & 104034 & 51468 & 33.3398193 & 81.7334009 \\
\hline AMB 70 & $S G$ & 2.3 & $i 56$ & 2.40 & 220 & 103919 & 51624 & 33.3398231 & 81.7327630 \\
\hline$A M B$ BD & DG & 1.2 & 157 & 245 & 225 & 103875 & 51400 & 33.3393601 & 81.7332733 \\
\hline AMB 9D & $D G$ & 1.2 & 155 & 242. & 222 & 103585 & 51263 & 33.3384953 & 81.7330699 \\
\hline AMB 100 & SG & 1.2 & 155 & 241.5 & 221.5 & 103293 & 51456 & 33.3381649 & 81.7319936 \\
\hline AME 110 & UG & 1.2 & 150 & 242.5 & 222.5 & 103132 & 51933 & 33.3395990 & 81.7304242 \\
\hline AMR :D & SG & 12 & 159 & 242 & 222 & 103:02 & 51902 & 33.3395703 & 81.7314202 \\
\hline \multicolumn{10}{|l|}{$\begin{array}{l}\text { Proposed } \\
\text { Wells }\end{array}$} \\
\hline$A M B 6 B$ & UG & 2 & 250 & 172 & 167 & 104083 & 51467 & $33.339 \times 1.93$ & 81.7334089 \\
\hline$A M B$ GA & UG & 2.3 & 300 & 132 & 127 & 104083 & 51467 & 33.3398193 & 81.7334089 \\
\hline$A M B \quad 10 B$ & $D G$ & 2 & 250 & 172 & 167 & 103293 & 51456 & 33.3381649 & 81.7319936 \\
\hline$A M B \quad 10 A$ & $D G$ & 2.3 & 300 & 132 & 127 & $103 \% 93$ & 51456 & 33.3381649 & 81.7319936 \\
\hline AMB 13B & $D G$ & 2 & 250 & 172 & 167 & 103000 & 51400 & 33.33742 .58 & 81.7315711 \\
\hline AMB 13A & $D G$ & 2.3 & 300 & 132 & 127 & 103000 & 51400 & 33.3374258 & 81.7315711 \\
\hline
\end{tabular}

\footnotetext{
Typo: $\quad D G=$ downgradiert

UG $=$ upgradiem

SG = sidegradient

Mothod: 1 = Auger

$z=$ Mud rotary

$3=$ Corts
} 
contamination in the A- and M-Area is underway as provided for in Section $J$ of Volume III to the SRS RCRA Part B (M-Area HWMF Post Closure Permit) as follows:

"... the specific corrective action program for the M-Area HWMF is a specific subset of the comprehensive remedial action effort currently in progress in the A/M Area. The remerial action program addresses other known and suspected sources of groundwater contamination (potential SWMUs), as well as the regulated unit. All of the area will be remediated under the auspices of this permit."

Groundwater contamination in the vicinity of the Metallurgical Laboratory HWMF is part of a contamination plume that underlies the A- and M-Areas. Groundwater movement in the water table, lower Congaree, and upper Congaree, is effected by the groundwater recovery system that is in operation in M-Area.

The placement of the wells in the Congaree, both upper and lower, was based on potentiometric data from existing wells which indicate the direction of groundwater rlow in these two zones as shown by Figures 4 and 5 . The available data indicate that the gradient in the upper Congaree is to the south southeast (SRS Coordinates) and the gradient in the lower Congaree is to the south southwest (SRS Coordinates).

By placing ciusters at AMB 6 and 10 vertical gradient movement of the plume may be examined.

\section{INSTALLATION OF WELLS}

The lower Congaree well in each cluster will be wire-line cored continuously, sampled every 2 feet, and geophysically logged to the total drilled depth. The samples will be analyzed for VOCs. Each well will be completed using mud rotary methods. Drilling and completion methods used for the well installation will follow Section V of DPSOP 254. Five (5) foot screens will be used for all wells. The wells will be screened in the same lithologic interval as the other upper and lower Congaree wells in the M-Area HWMF. This will enable the data to be incorporated into the SRS M-Area HWMF program.

\section{DEVELOPMENT OF WELLS}

The drilling contractor will have 1 drilling crew and 1 developing crew available for this project. Development of all wells will begin within 4 days of installation of each well. Prompt development of the wells is necessary to ensure that they are thoroughly developed. After the we'ls have been developed, slug tests will be performed to determine the hydraulic conductivity $(\mathrm{K})$ after which pumps will be installed. 
Figure 4: Upper Congaree Potentiometric Map 1090

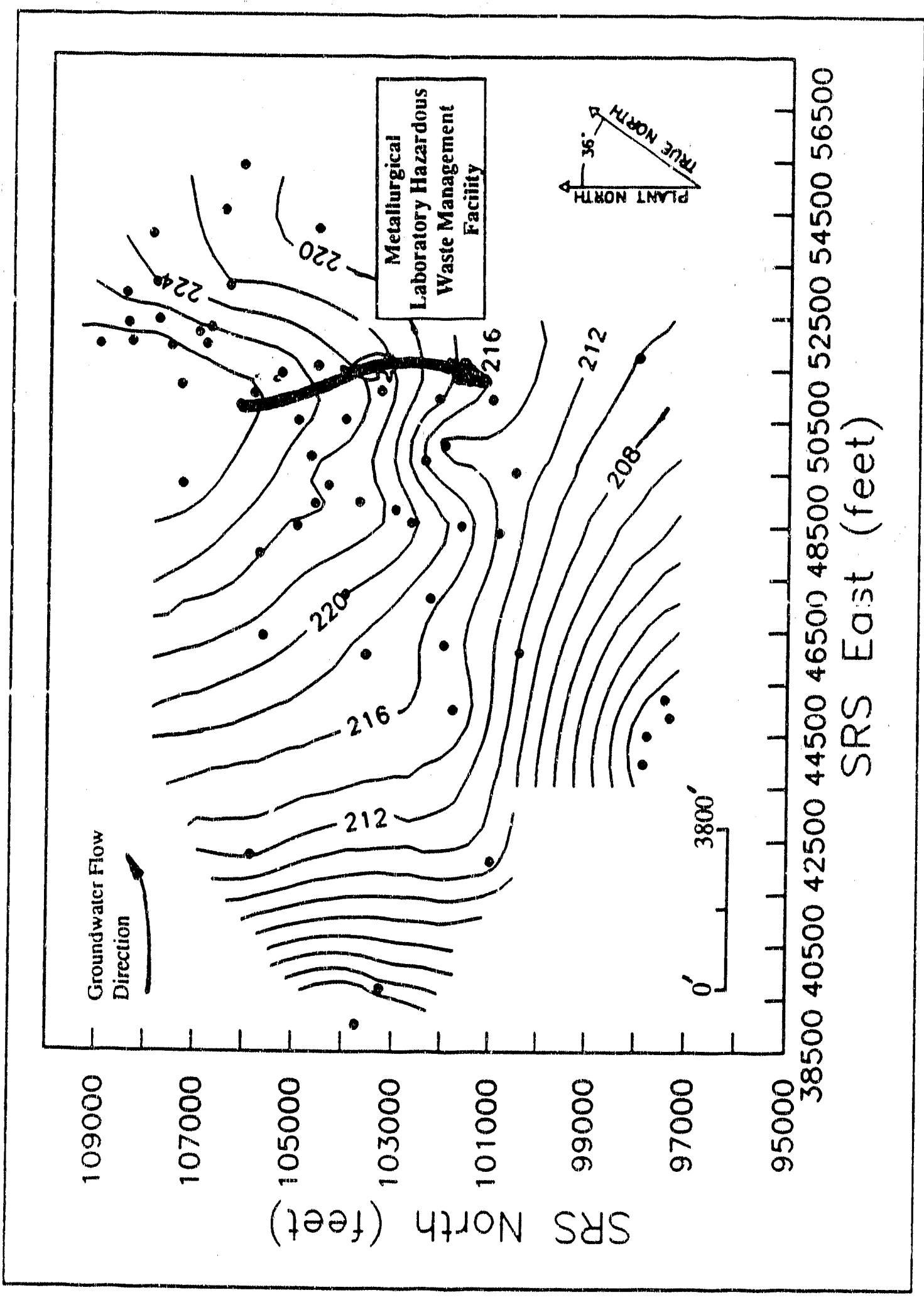


Figure 5: Lower Congaree Potentiometric Map 1Q90

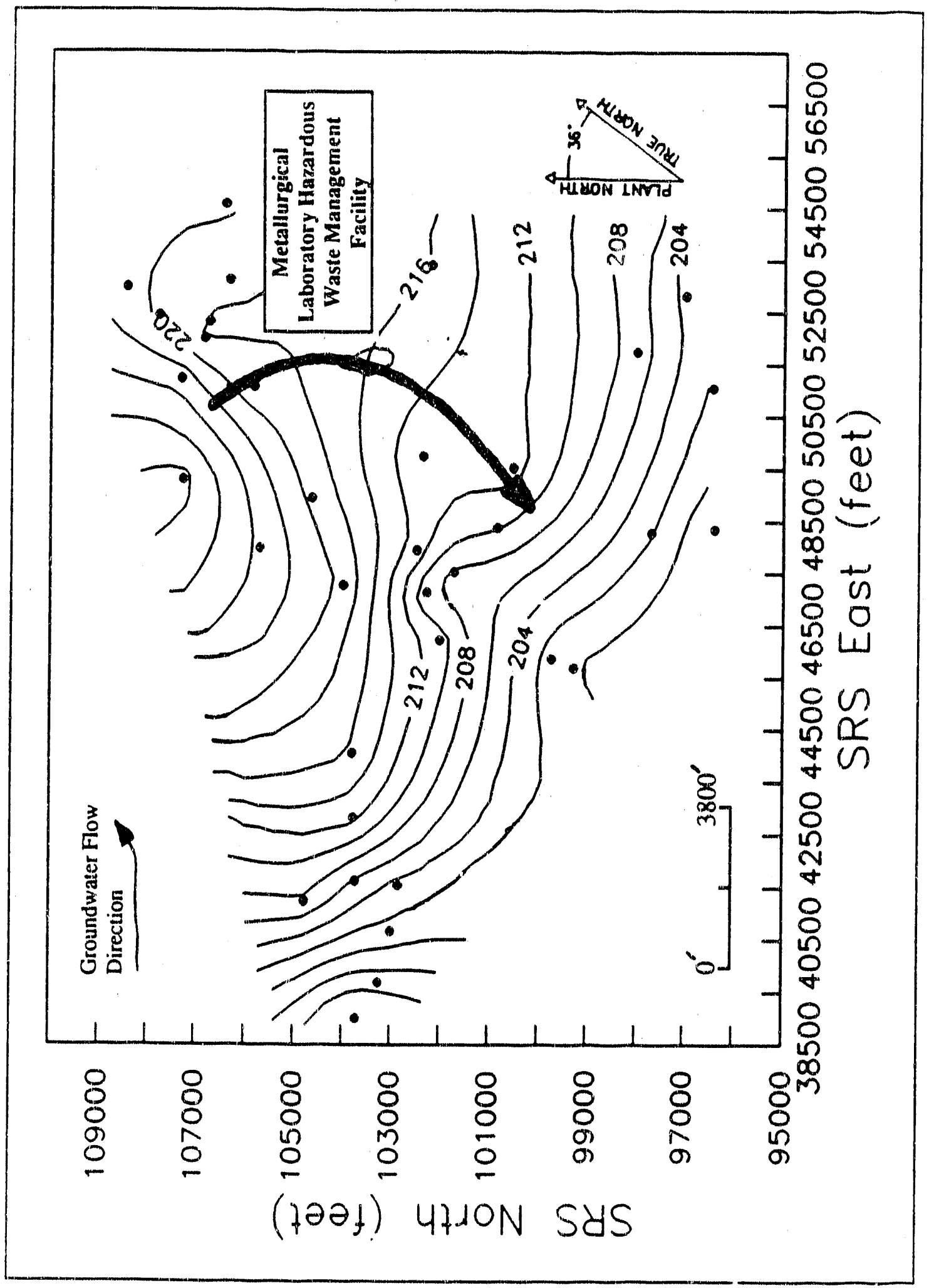




\section{SAMPLING AND ANALYSIS}

All MLHWMF monitoring wells will be sampled and analyzed for the constituents listed in Table 4. Sampling and analysis of the six new wells will be done on a quarterly basis for the first year. Results from the first year of groundwater analyses will be used to determine the sampling schedule for following years. The additional parameters indicating groundwater contamination listed in Table 4 were selected based on knowledge of the waste stream discharged to the basin. Samples will be collected and shipped according to procedures outlined in Section XI DPSOP 254. rroundwater monitoring samples will be analyzed using EPA approved methods.

\section{DATA EVALUATION}

The analytical results will be used to construct contaminant maps and cross-sections. Monitoring data summary tables and graphs of indicator parameters will be constructed.

\section{SCHEDULE}

Installation of the proposed MLHWMF Assessment monitoring wells is scheduled to begin. as soon as all of the appropriate approvals have been obtained. Table 5 depicts the schedule of activities for the Metallurgical Laboratory HWMF Part B Permit Revision. The results obtained from these additional wells will be presented in the revised part $B$ permit application and in the quarterly groundwater reports for the MLHWMF.

\section{SAFETY}

Standard SRS safety procedures for well installation, as described in DPSOP 254, will be followed.

\section{QUALITY ASSURANCE / QUALITY CONTROL}

The QA/QC methods for drilling presented in DPSOP 254 will be followed. 
Table 4: Indicator parameters for detection monitoring at the Metallurgical Laboratory Hazardous Waste Management Facility with their approved EPA Analytical Methods

Parameters for establishing drinking water suitability

Arsenic

Barium

Cadmium

Chromium

Fluoride

Lead

Mercury

Nitrate as $\mathrm{N}$

Selenium

Silver

Endrin

Lindane

Methoxychlor

Toxaphene

2,4-D

2,4,5-TP Silvex

Radium

Gross Alpha

Gross Beta

Depth to water surface
EPA 206.3

EPA 200.7

EPA 200.7

EPA 200.7

EPA 300.0

EPA 239.2

EPA 245.1

EPA 300.0

EPA 206.3

EPA 200.7

EPA $608 / 8080$

EPA $608 / 8080$

EPA $608 / 8080$

EPA $608 / 8080$

EPA $608 / 8080$

EPA $608 / 8080$

EPA 900.1

Standard Methods 703

Standard Methods 703

Parameters for establishing groundwater quality

Chloride

Iron

Manganese

Phenols

Sodium

Sulfate
EPA 300.0

EPA 200.7

EPA 200.7

EPA 420.2

EPA 200.7

EPA 300.0

Parameters for indicating groundwater contamination

$\mathrm{pH}$ (field)

Specific Conductance (field)

Toral Organic Carbon

Total Organic Halogens
EPA 415.1

EPA 450.1 
Additional parameters indicating groundwater contamination

Trichloroethylene

Tetrachloroethylene

Carbon Tetrachloride

Vinyl Chlorice

1,1 Dichloroethylene

Methyl Methacrylate
EPA 624

EPA 624

EPA 624

EPA 624

EPA 624

EPA 624 
Table 5: Schedule of Activities for the Metallurgical Laboratory HWMF Part B Permir Revision

Schedule Name: Motallurgtcal Laboratory GhMF Part. B Permit Revision

As of Date : 12-Jun-90 9:00am Schodule F1lo: C:\TL3\DATA

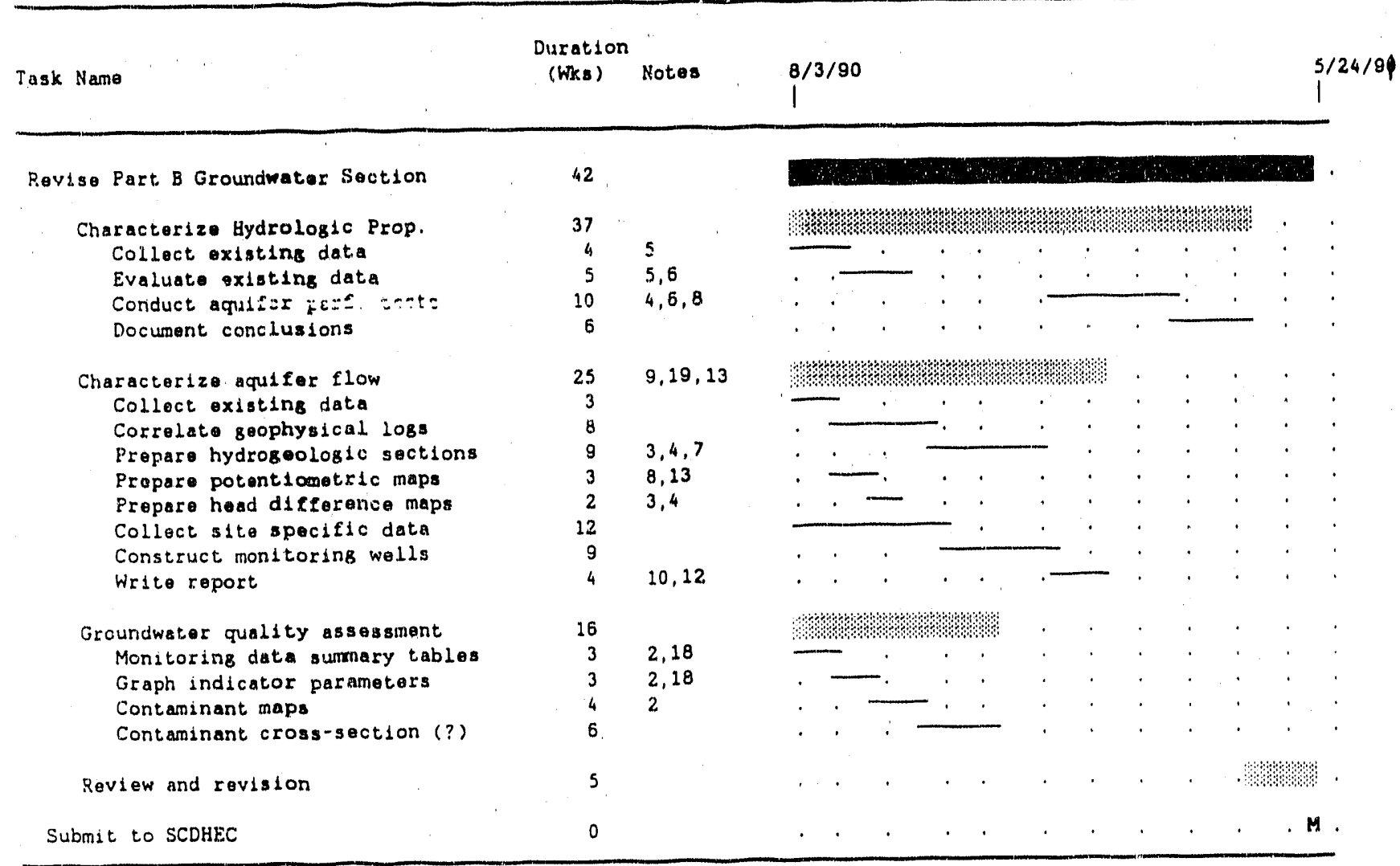

Notes: This colum indicates which NODs are addresed by each task. 
APPENDIX A

TRENDS OF CONTAMINANTS FROM $4 Q 88$ TO $2 Q 90$

A-1 


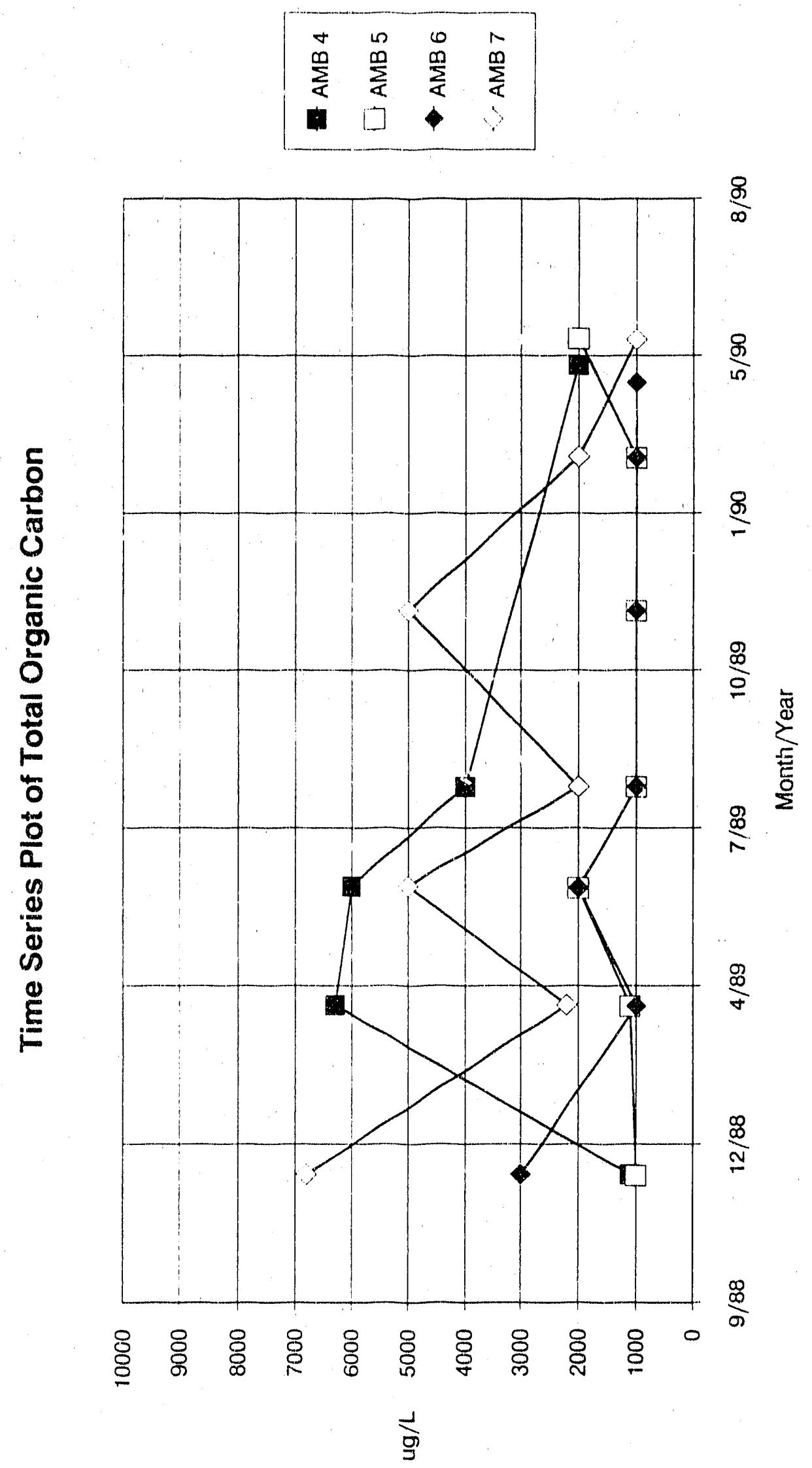




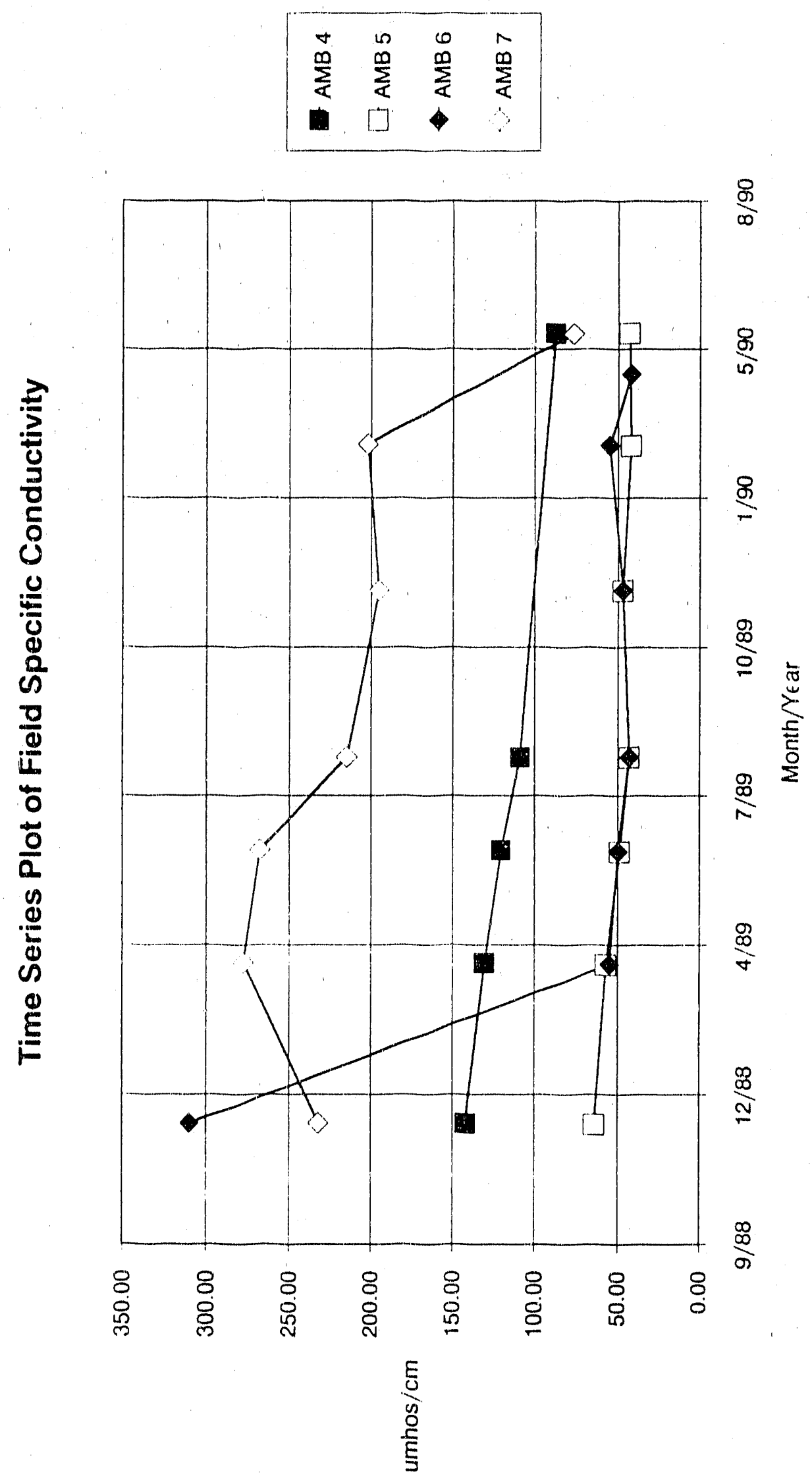




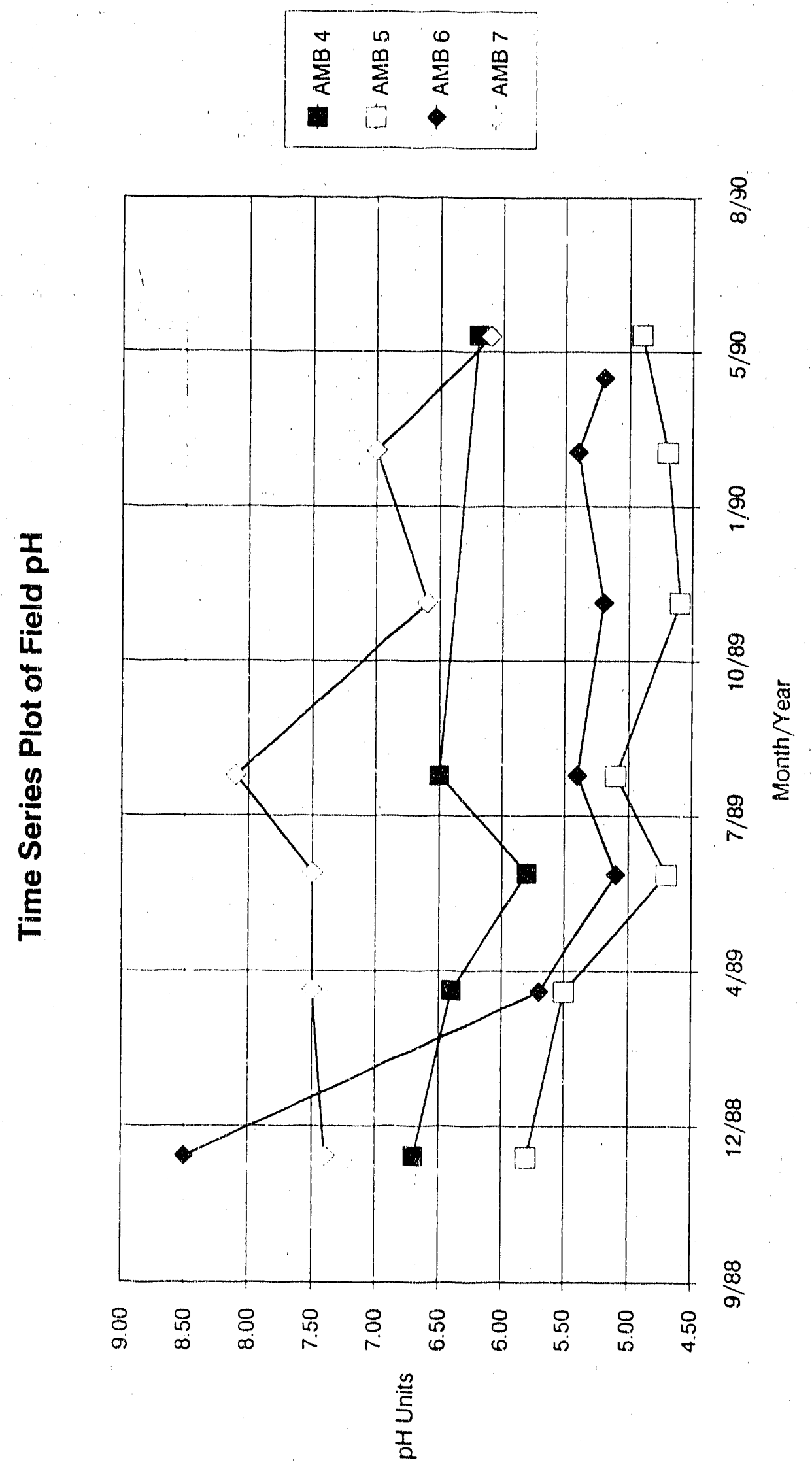




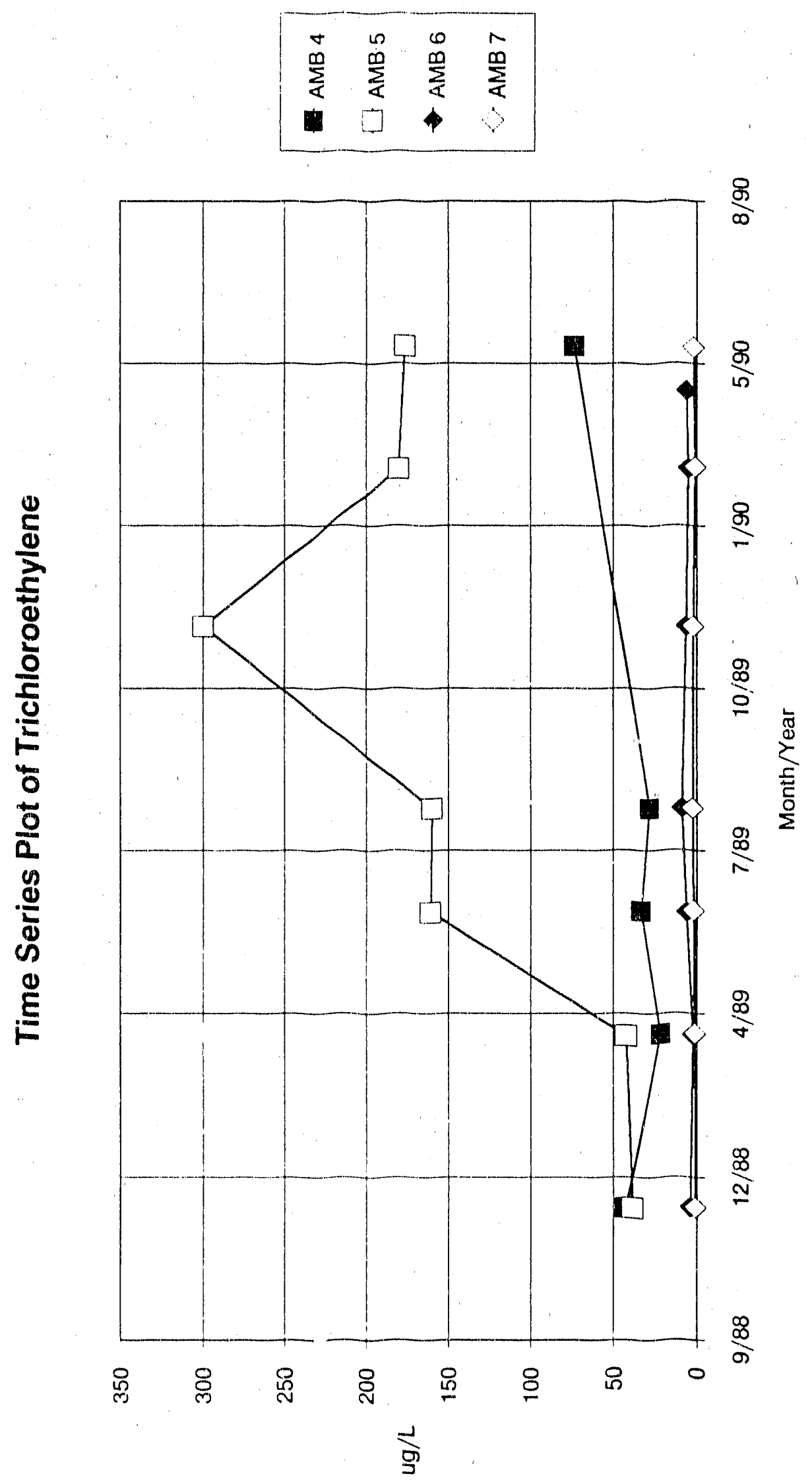




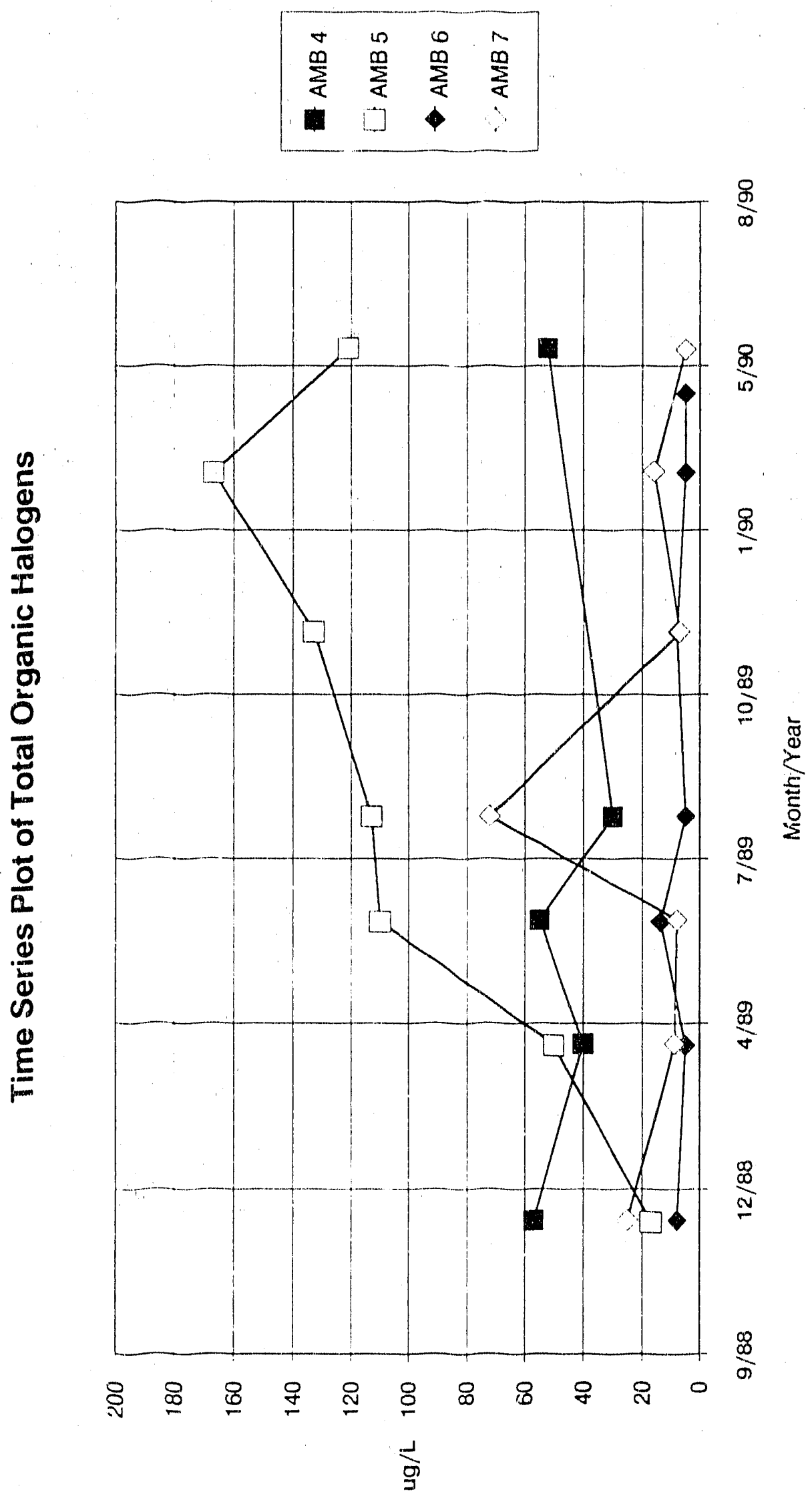




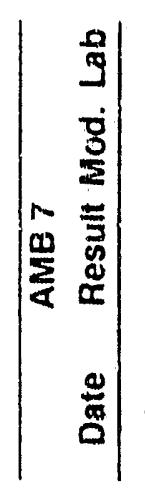

出出出岁岕岕

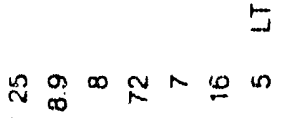

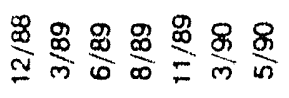

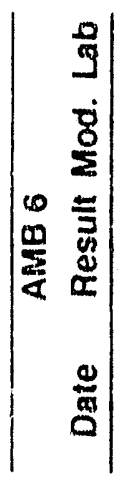

出出岁岕岁

コココ

$\infty n \pm n$ as $n$

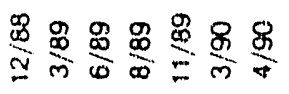

出出岁嵌嵌

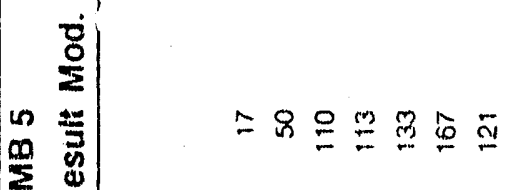

$\sum_{<} \underset{d}{0}$

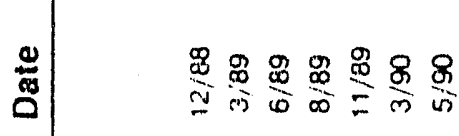

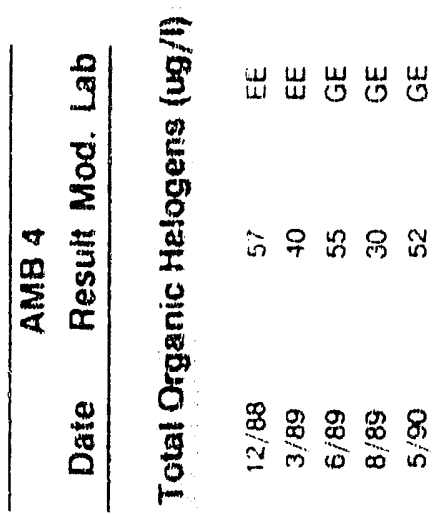

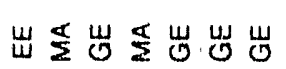

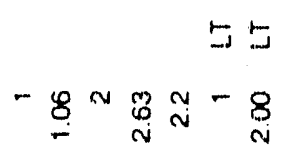

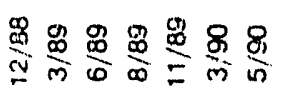

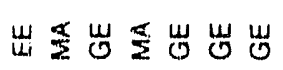

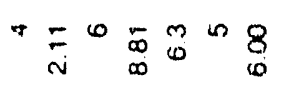

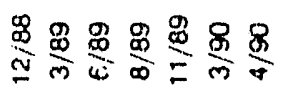

出芒出嵌岁出岁

gु

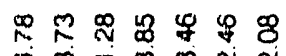

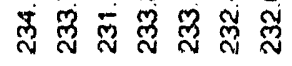

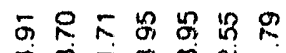

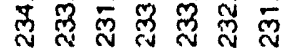

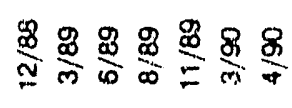

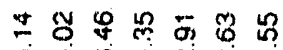

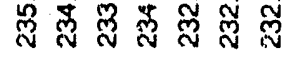

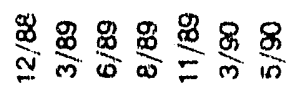

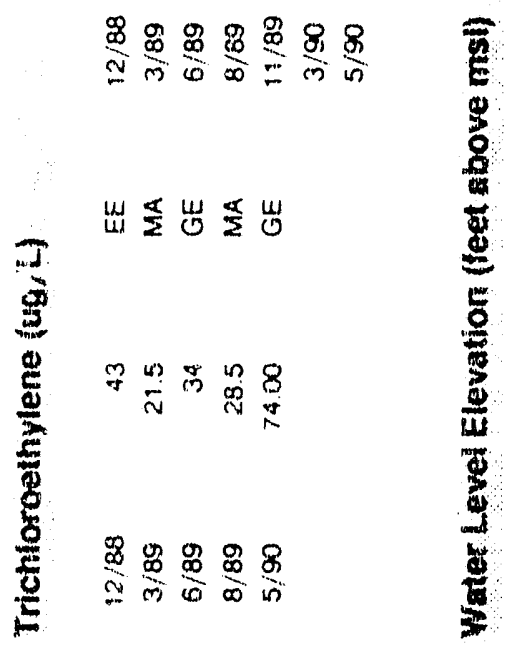

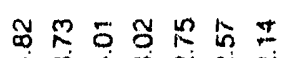

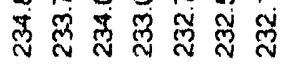

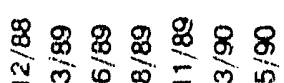




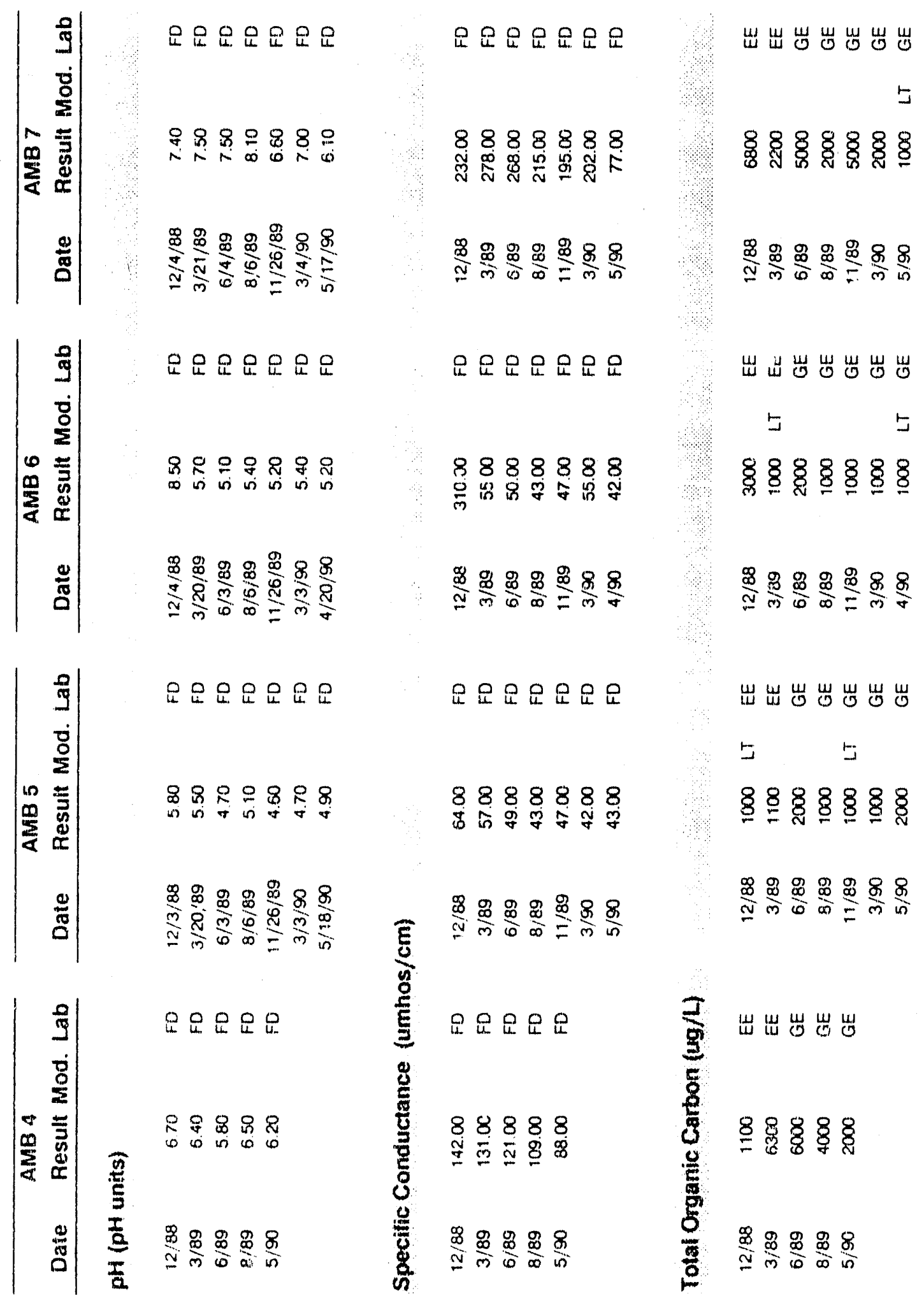


APPENDIX B

WELL CONSTRUCTION INFORMATION

B-1 
iste $30-5$

\section{SRP MONITORING WELL COÑSTRUCTION DETAILS}

DRILLING SUBCONTRACTOR 1) $1 T C$

DFILLER

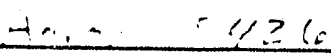

DATE OF INSTALLATION

$10 / 0 \operatorname{lin} 2$

TECH. O.S./CO. NAME L'Crine / in etinghine,

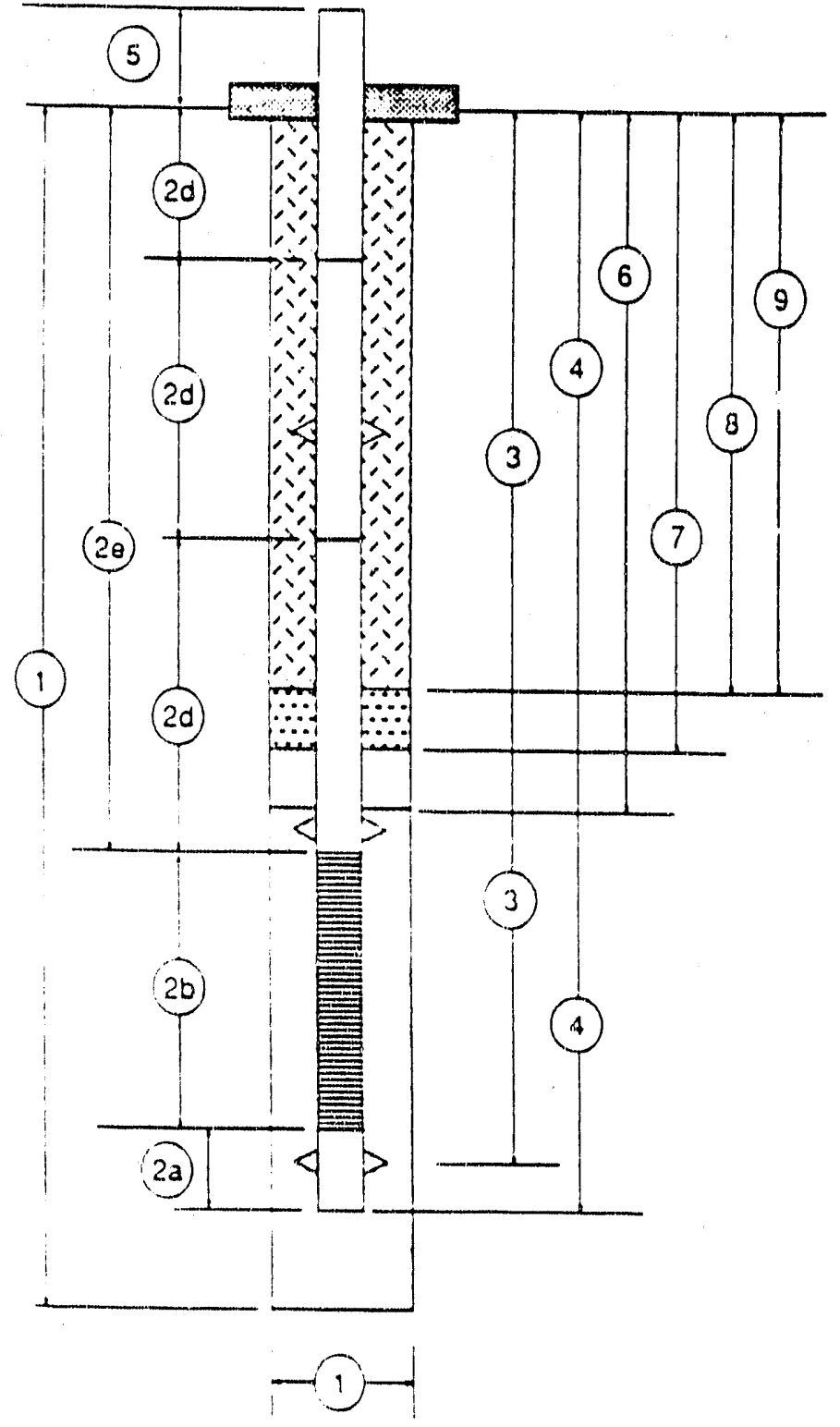

NOTE: ALL MEASUREMENTS

ARE FROM GROUND

SURFACE AT START

OF BORING - MEASUREMENTS

TO NEAREST 0.1 FOOT.

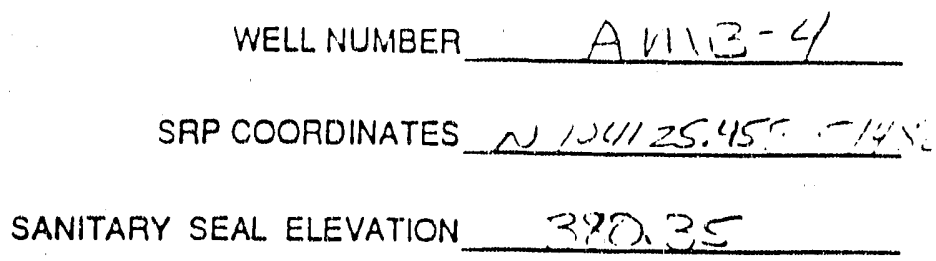

1) Total drilled depth/hole dianneter_165'/974"

2) Casing/Screen Tally (Measured to Nearest 0.01 Foot)

(a) Sump \& Plug _ _. $4,9^{\prime}$

(b) Scroon Longth 20

(c) Screon Type/Slat Size PUC $51440 / 0.015^{\prime \prime}$

(d) Casing Joint Lengths (Measured in up-

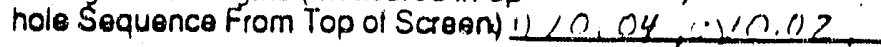

(3) $<0.01^{\prime}(-1) 0.02^{\prime}, 1020 z^{\prime}, 0.13^{\prime},-1 / 0.02 z^{\prime}$

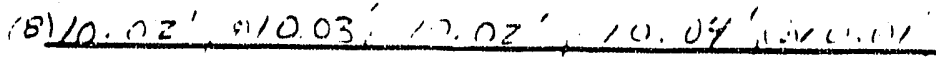
(1) $100.02^{\prime} \cdot \ldots 10.22$

(0) Total Langth of Casing __ $\angle 3.5 .8$

(1) Type of Casing___f

3) Depths to Centralizers $15 \%$

4) Total Depin of Installed Well $161=$

5) Casing Stick Up (Standard 2.5' A.G.S.) _ ב

6) Depth to Top of Filter Pack LI

Quantry (Bags) 2* Sizo 1).45.1).5 m.m

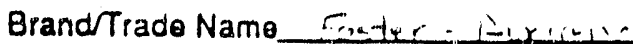

7) Depth to Top of Fine Sand Seal $10 E^{\prime}$

Quantity (Sacks)

8) Depth 10 Top of Bentonite Seal 101

Quantity (Buckets) 3

9) Thicknoss of Groun 101

Total Grout Quantity (Bags) 
OSR $30 \cdot 5$

\section{SRP MONITORING WELL COÑSTRUCTION DETAILS}

ORILLING SUBCONTRACTOR

DRILLER

DATE OF INSTALLATION

$29 / 12 / \cdots$

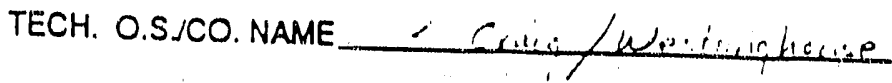

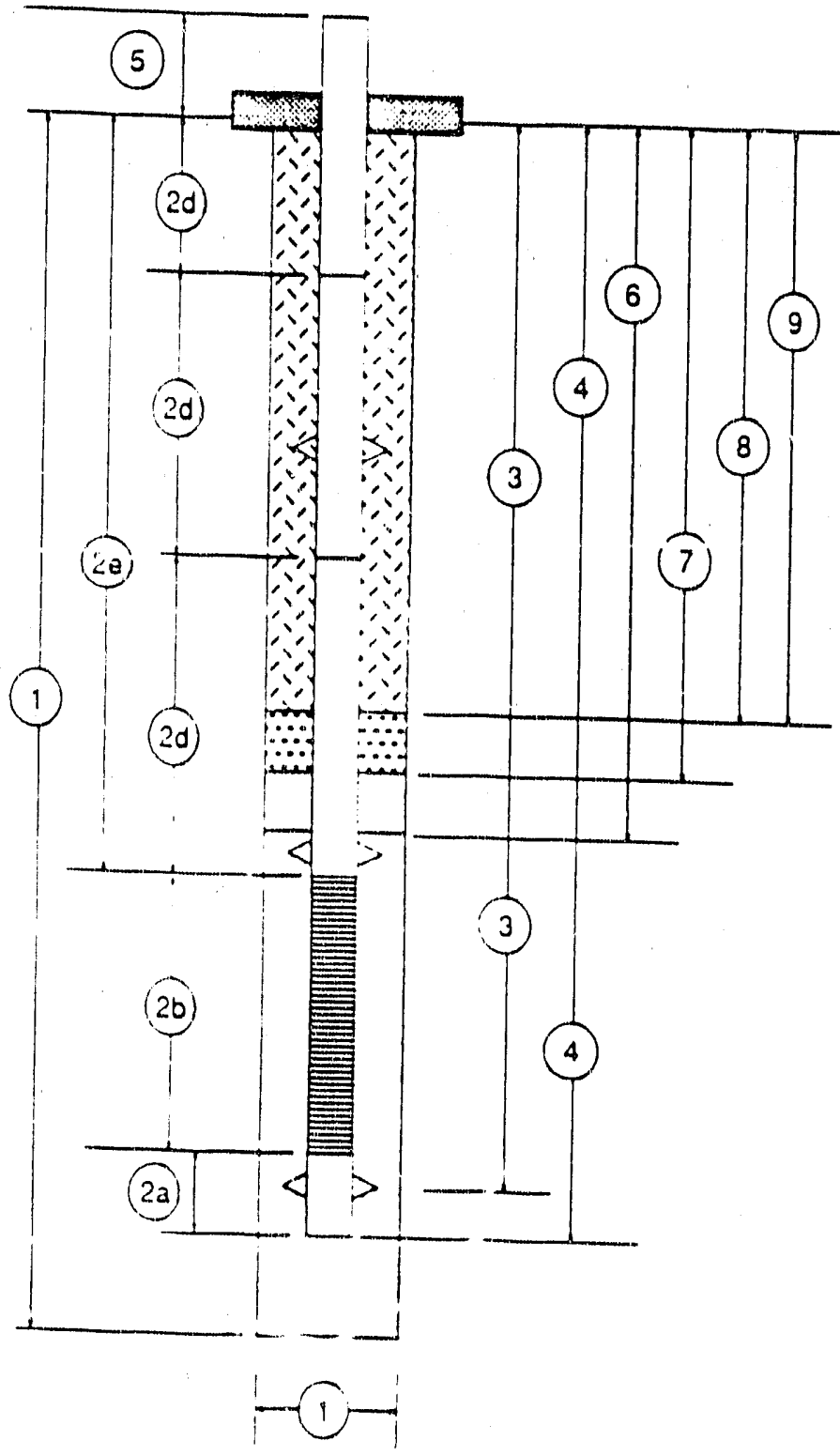

NOTE: ALLMEASUREMENTS

ARE FROM GROUND

SURFACE AT START

OF BORING - MEASUREMENTS

TO NEAREST 0.1 FOOT.
WELL NUMBER__ $\quad$ _::1B-C-

SRP COORDINATES N1O4\% IE CUIC:

SANITARY SEAL ELEVATION

$\div>7.1^{\prime} \quad 1, c$

1) Total drilled depthmole diameter_165: 27/4

2) Casing/Screen Tally (Measured to Nearest 0.01 Foot)

(a) Sump \& Plug _ $5.2 \mathrm{sin}$

(b) Scroen Length 20.04

(c) Scroen TyperSlor Sizo PyC $=1,4(1) / 0.5 .1 .11$

(d) Casing Joint Lengths (Measured in up-

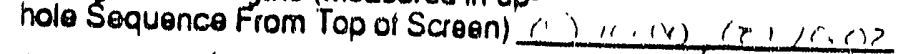
(3) $10,0, E^{\prime}$ (c) $<0,2,(-), 0.0 \% 11,1,1,2$

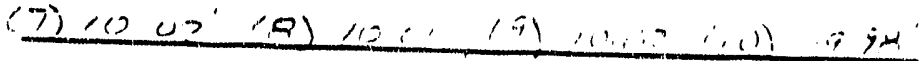

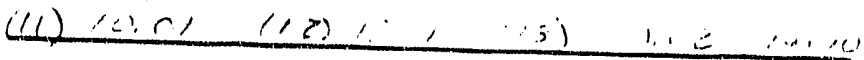

(8) Total Length of Casing _ 135.5

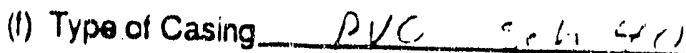

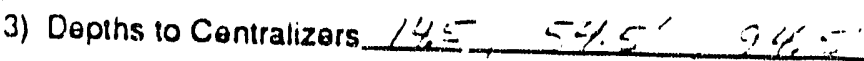

$135.5^{\prime}, 1,1 . \cdots$

4) Total Depth of Installed Woll __ L L O.9

5) Casing Stick Up (Standard 2.5' A.G.S.)

6) Depth to Top of Filter Pack 126

Quantity (Bags) 15 Sizo $045-0.55 \mathrm{~mm}$

BrandTrado Name Fortei - 1)roiana

7) Depin to Top of Fine Sand Seal 21

Quantity (Sacks) 2

8) Depth to Top of Bentonite Seal $115^{1}$

Quansity (Bucksts) 2

9) Thicknoss of Groun 115 
DRILLING SUBCONTRACTOR WTC

DRILLER_ \& 4 . " $" 2>0$

DATE OF INSTALLATION $\cap 0 / 14 / 99$

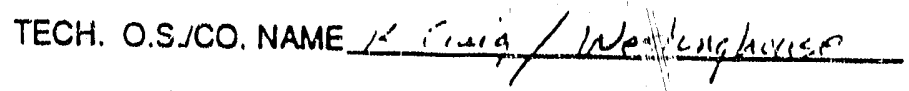

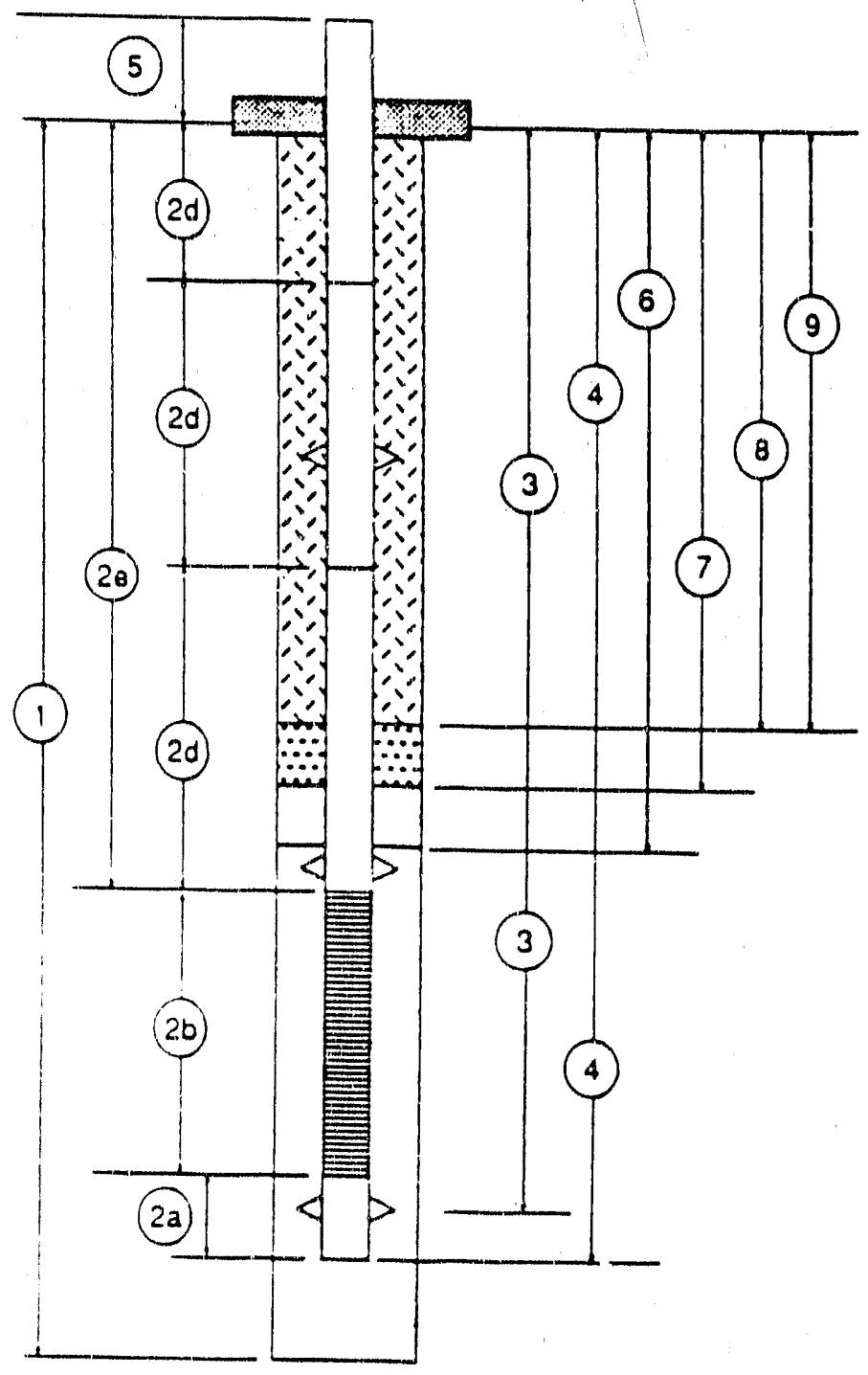

NOTE: ALL MEASUREMENTS ARE FROM GROUND SURFACE AT START OF BORING - MEASUREMENTS TO NEAREST 0.1 FOOT.

1) Total drilled depthnole diamoter__ $165^{\circ} / 9 \% "$ 2) Casing/Screen Tally (Measured to Nearest 0.01 Fool)

(a) Sump \& Plug _ $5=2 z^{\prime}$

(b) Screen Longth 100.06

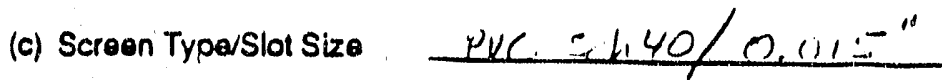

(d) Casing Joint Lengths (Measured in uphole Sequence From Top of Screen) (1) 10.01 (2) 10.12 (3) $10.000^{-},(4) \%: 9^{\prime}(1) 10.0 \%, 1010$

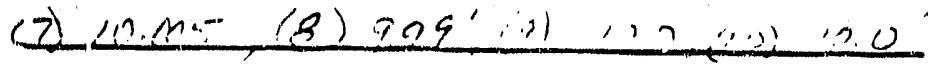
(1) $\left.10.00 \sigma^{\prime},(2) 10.02^{\prime}, 21,1\right)^{\prime}(16) 50 \%$

(e) Tolal Longth of Casing __ $\angle 32.5$

(i) Type of Casing PUC $\mathrm{SCH} 4 \mathrm{H}^{\prime \prime C}$

3) Depths to Centralizers _l.6, $131.6^{\prime}, 5-3.6^{\prime}$

4) Total Depth of Installod Well $158.0 .3^{\prime}$

5) Casing Stick Up (Standard 2.5' A.G.S.) Z $2.5^{\prime}$

6) Depth to Top of Filter Pack $125.5^{-1}$

Quantry (Bags) Sizo $045^{-} \cdot 0 .-5 \cdot$ ond

Brand/Trado Namo_Tieter - Duxicina

7) Depth to Top of Fine Sand Seal __ 123.5

Quantity (Sacks) 1.5

8) Depth to Top of Bentonite Seal _L_ 118.

Quantity (Buckass) 2

9) Thickness of Grout

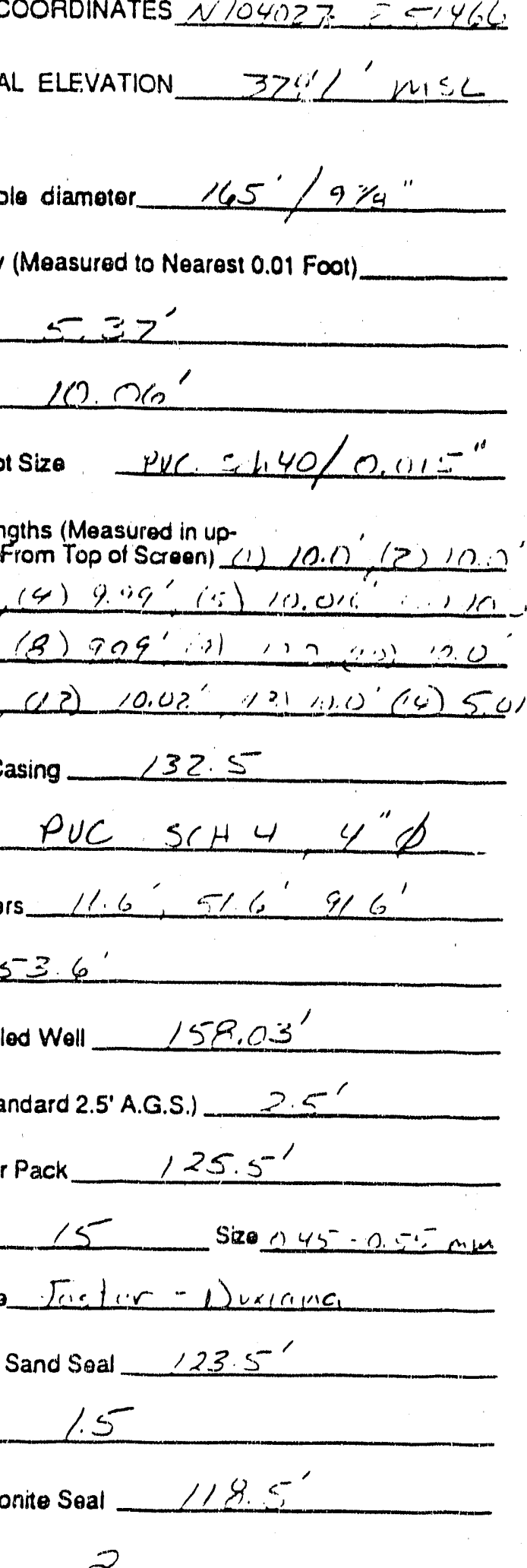


ORILLING SUBCONTRACTCA HITC,

DRILLER sulee. $/$ Jullinu daren

DATE OF INSTALLATION_ G: $/ 3 / 285$

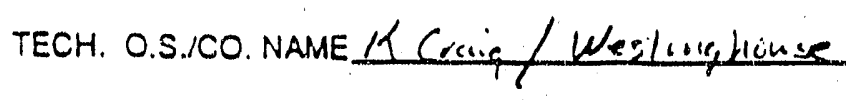

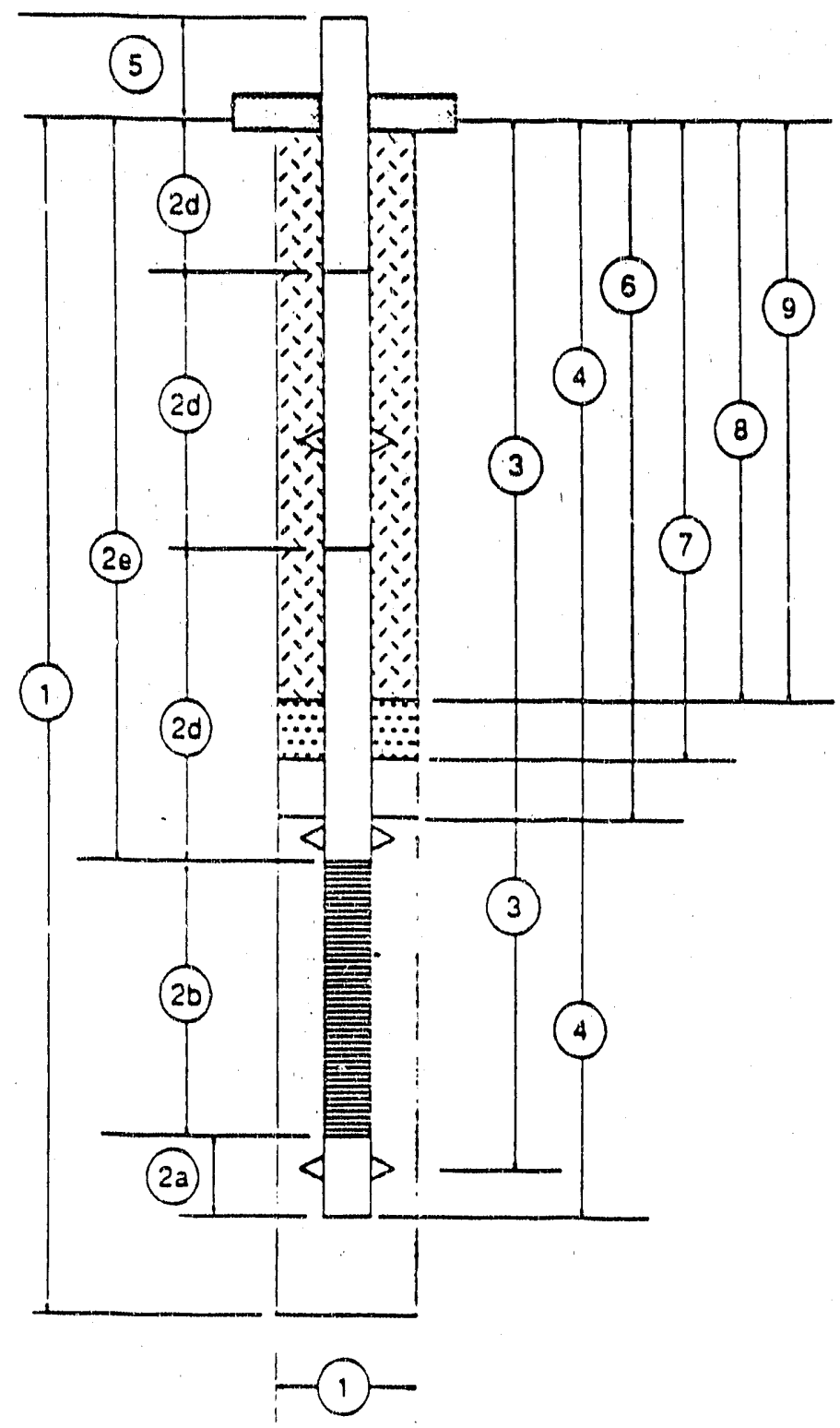

\begin{aligned} & WELL NUMBER $\frac{A M B-7}{N 103919.92} \\ &$ SRP COORDINATES E 516.24 .91 \\ & \hline\end{aligned}

SANITARY SEAL ELEVATION $369.87^{\prime}$

1) Total drilled depthmole diameter_ $1560^{\prime} / 970^{\circ}$

2) Casing/Screen Tally (Measured to Nearesi 0.01 Foot)

(a) Sump \& Plug $5.41^{\prime}$

(b) Scroen Length $\quad 20,04$

(c) Scroen TyporSlot Sizo PrC sin 40 shtied $/ 0.015$

(d) Casing Joint Lengths (Measured in uphole Sequence From Top of Screon) (1) 10.0.' 2 (2) $10.02^{\prime}$ (3) $10.02^{\prime}(4) 10.02^{\prime}(5) 10.02^{\prime}(6) 10.01^{\prime}$ (2) $10.0 .3^{\prime}\left(89 / 0.02(9) \quad 10.07^{\prime}(10) / 0.0^{\prime}\right.$ (11) $10.02^{\prime}(12) 10.02 \quad(15) 10.02^{\prime}$

(0) Total Length of Casing. 130,3 ,

(i) Type ol Casing pUc, $\leq, h \& 0,4^{\circ}$

3) Depths to Contralizars_ $5^{\prime}, 45^{\prime}, 85^{\prime}$ $125^{\prime}, 147^{\prime}$

4) Total Depth of Installed Woll _ $15 / .3^{\prime}$

5) Casing Stick Up (Standard 2.5' A.G.S.) Z__. Z '

6) Depin to Top of Filter Pack_ $12 / .0^{\prime}$

Quantity (Bags) 17 Size $0.75-0.55 \mathrm{~mm}$ Brand/Trado Name Eoster - Dixiana

7) Depth to Top of Fine Sand Seal _ $1 / 8,5^{-}$

Quantity (Sacks)

8) Depth to Top of Bentonite Seal

114.0

Quantity (Buckets)

9) Thicknoss of Grout $\therefore$

Total Grout Ouaniny (Rege) _ $\quad 56$ 
DRILLING SUBCONTRACTOR Graves -IIILLER Steve Rogers/ $/ 701$ (SC)

DATE CF INSTALLATION $10-27-89$

TECH. O.S./CO. NAME R. J. Hunt/SIrrine

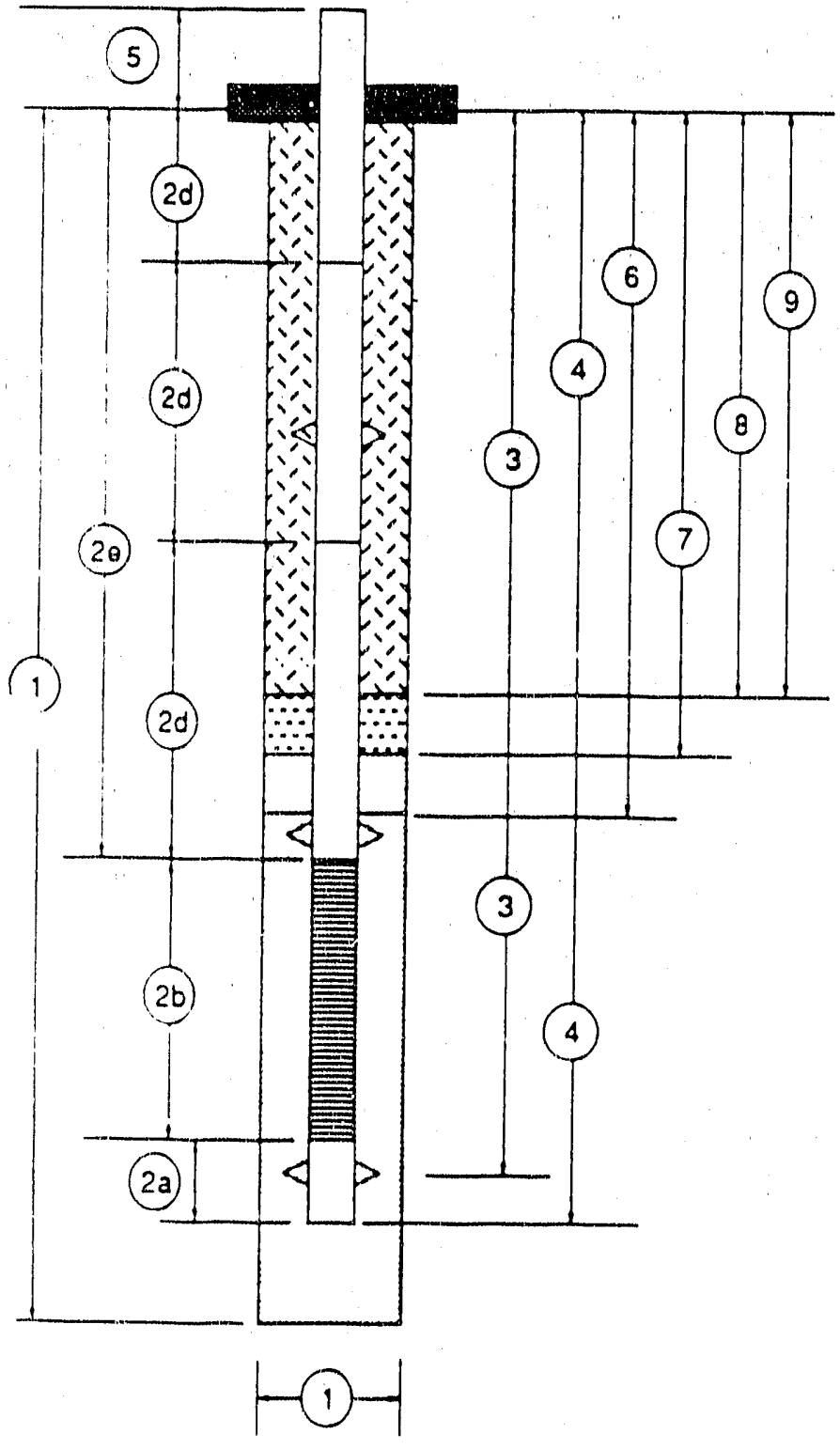

NOTE: ALL MEASUREMENTS ARE FROM GROUND SURFACE AT START OF BORING - MEASUREMENTS TO NEAREST 0.1 FOOT.

\begin{aligned} & WELL NUMBER \multicolumn{1}{c}{ AMB-8D } \\ & \cline { 2 - 2 } N 103874.74 \\ & SRP COORDINATES E 51400.46 \\ & \hline\end{aligned}

SANITAAY SEAL ELEVATION

369.61

1) Total drilled depth/hole diameter $157 \mathrm{ft} . / 117 / 8 \mathrm{ln}$.

2) Casing/Screen Tally (Measured to Nearest 0.01 FootL $153.52 \mathrm{ft}$.
(a) Sump \& Plug $5.36 \mathrm{ft}$.
(i) Screen Length
$20.01 \mathrm{H}$.

(c) Screen Type/Slot Size

Sch. 40 PVC/0.015 In.

(d) Casing Joint Lengihs iMeasured in uphole Sequence From Top of Screan)

$10.00 / 10.01 / 10.01 /$ $10.01 / 10.02 / 10.01 / 10.01 / 10.02 / 10.02 / 10.02 / 10.01 / 10.00 /$ 8.01

(e) Total Length of Casing

$128.15 \mathrm{H}$.

(f) Type of Casing Sch. 40 PVC, 4 in. diameter

3) Depths to Centralizers $18 / 45 / 85 / 125 / 149$

4) Total Depth of Installed Well $151.02 \mathrm{ft}$.

5) Casing Stick Up (Slandard 2.5' A.G.S) $2.5 \mathrm{it}$.

6) Depth to Top of Filter Pack $122.2 \mathrm{t}$

Quantity (Bags) 16 Size $\quad F \times \cdot 50$ Brand/Trado Name Foster-Dixlana

7) Depth to Top of Fine Sand Seal $120.5 \mathrm{H}$

Quantity (Sacks) 2

8) Depth to Top of Bentonite Seal $111.2 \mathrm{H}$

Quantity (Buckets)

2

- Fine sand to $108.4 \%$.

9) Thicknoss of Grout $108.4 \mathrm{t}$

Total Grout Quantity (Bagn) _ 10/12/8/19 
DRILLING SUBCONTRACTOR Graves

ILLER Steve Rogers/ $\$ 701$ (SC)

DATE OF INSTALLATION 10-18-89

TECH. O.S./CO. NAME R. J. Hunt/SIrrine

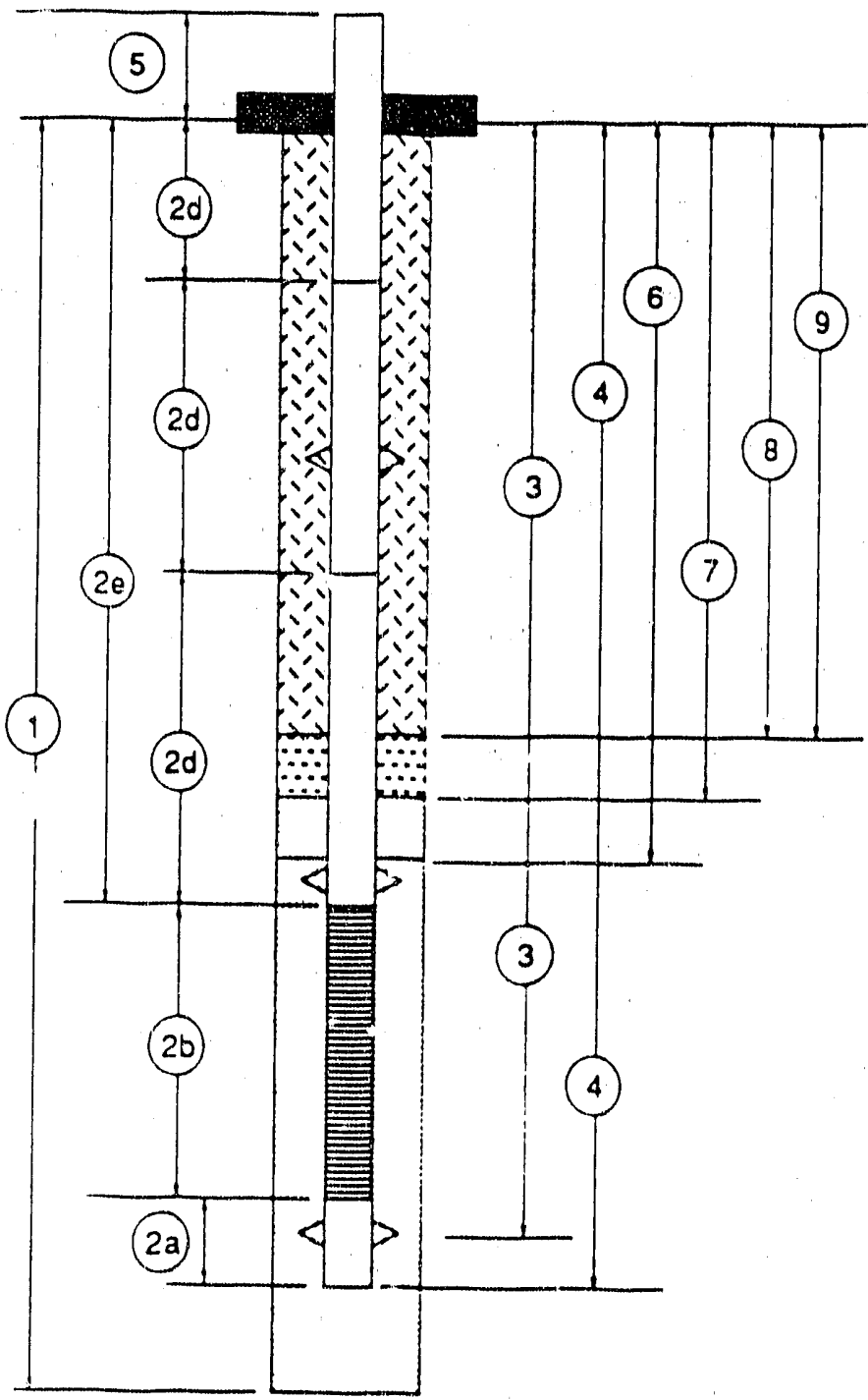

NOTE: ALL MEASUREMENTS ARE FROM GROUND SURFACE AT START OF BORING - MEASUREMENTS TO NEAREST 0.1 FOOT.

\begin{tabular}{rc} 
WELL NUMBER & AMB-9D \\
\cline { 2 - 2 } & N 103585.24 \\
SRP COORDINATES & E 51262.99 \\
\hline
\end{tabular}

SANITARY SEAL. ELEVATION 367.88

1) Total drilled depthmole diameter $155.0 \mathrm{ft} . / 117 / 8 \mathrm{in}$.

2) Casing/Screen Tally (Moasured to Noarest 0.01 Foot) 153.87 if.
(a) Sump \& Plug $5.37 \mathrm{H}$.
(b) Screon Length $20.00 \mathrm{H}$

(c) Scroen Typo/Slot Size

Sch. 40 PVC/0.015 in.

(d) Casing Joint Lengths (Measured in uphole Sequence From Top of Screenl 10.00/10.02/10.01/ $10.00 / 10.00 / 10.01 / 10.00 / 10.00 / 10.00 / 10.00 / 10.00 / 10.01 /$ 8.45

(o) Ta!a! -ongth of Casing

$128.5 \mathrm{ft}$.

(1) Type of Casina Sch. 40 PVC, 4 In. dlameter

3) Depths to Centralizers__ 18/44/84/124/148

4) Total Depth of Installed Well $151.37 \mathrm{tt}$.

5) Casing Stick Up (Standard 2.5' A.G.S) $2.5 \mathrm{ft}$.

6) Depth to Top of Fitter Pack $120.4 \mathrm{H}$

Quantity (Bags) 18
Size $\quad F X .50$ Brand/Trade Name Foster-Dixlana

7) Depth to Top o! Fine Sand Seal $118.0 \mathrm{ft}$.

Quamity (Sacks) 2

8) Depth to Top of Bentonite Seal $109.5 \mathrm{ft}$.

Quantity (Buckets) 3

- Fine sand to $107.5 \mathrm{ft}$.

9) Thickness of Grout $107.5 \mathrm{ft}$. 
DRILLING SUBCONTRACTCA Graves AILLER Steve Rogers/ $\$ 701$ (SC)

DATE OF INSTALLATION $\quad 11.1 .89$

TECH. O.S./CO. NAME R. J.HUnt/SIrrine

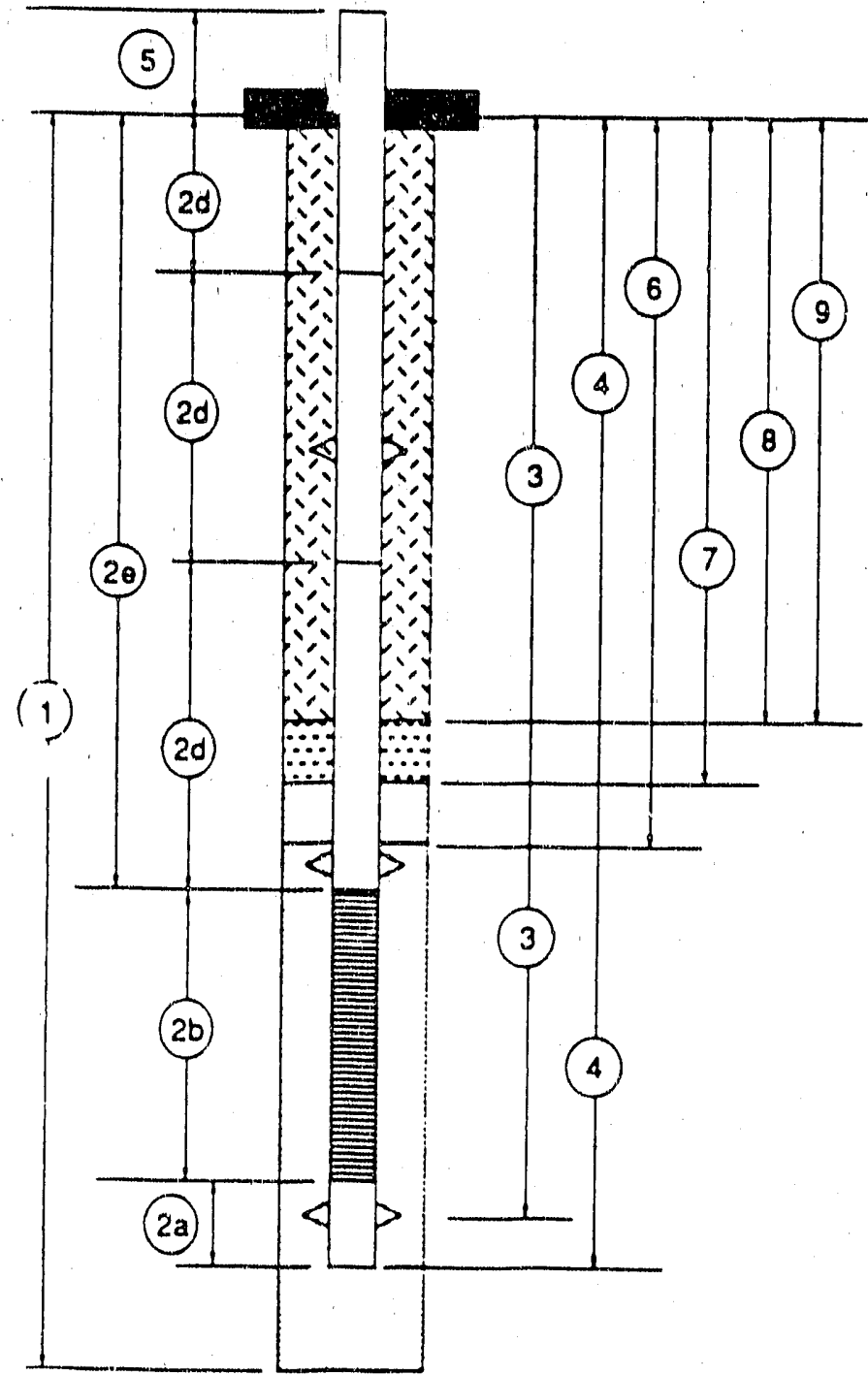

NOTE: ALL MEASUREMENTS ARE FROM GROUND SURFACE AT START OF BORING - MEASUREMENTS TO NEAREST 0.1 FOOT.

\begin{tabular}{|c|c|}
\hline WELL NUMBER & AMB. $10 D$ \\
\hline SRP COORDINATES & $\begin{array}{l}N 103293.40 \\
E 51455.96\end{array}$ \\
\hline SEAL ELEVATIOR & 365.51 \\
\hline
\end{tabular}

1) Total drilled depth/hole diameter $155.0 \mathrm{H} . / 117 / 8 \mathrm{in}$.

2) Casing/Screen Tally (Measured to Nearest 0.01 FootL $151.91 \mathrm{Ht}$.
(a) Sump \& Plug
$5.38 \mathrm{H}$.
$20.02 \mathrm{ft}$.

(b) Scroen Longth

(c) Screen Type/Slot Size

Sch. 40 PVC/0.015 In.

(d) Casing Joint Lengths (Measured in uphole Sequence From Top of Screen)

$10.00 / 10.01 / 10.01 /$ $10.01 / 10.00 / 10.02 / 10.01 / 10.02 / 10.01 / 10.01 / 10.00 / 10.01$ 6.40

(e) Total Length of Casing

126.5111.

(i) Typo of Casing Sch. 40 PVC, 4 In. dlameter

3) Depths to Centralizers $13 / 43 / 83 / 123 / 147$

4) Total Depth of Installed Well_ $149.41 \mathrm{ft}$.

5) Casing Stick Up (Standard 2.5' A.G.S) $2.5 \mathrm{Ht}$.

6) Depth to Top of Fitter Pack $122.2 \mathrm{H}$.

Quantity (BagsL $14 \quad-\quad$ Size FX.50

Brand/Trade Name: Foster-DIxlana

7) Depth to Top of Fine Sand Seal. $119.5 \mathrm{H}$.

Quantity (Sacks) 2

8) Depth to Top of Bentonite Seal $111.2 \mathrm{H}$

Quantity (Buckets) 3

- Fine sand to $109.0 \mathrm{H}$.

9) Thickness of Grout 109.0 \%. 
DRILLING SUBCONTRACTOR Graves

IILLER Jim Hall/ $\$ 653$ (SC)

DATE OF INSTALLATION $\quad 6 / 12 / 89$

TECH. O.S./CO. NAME

A.M. Pelletler/SIrrine

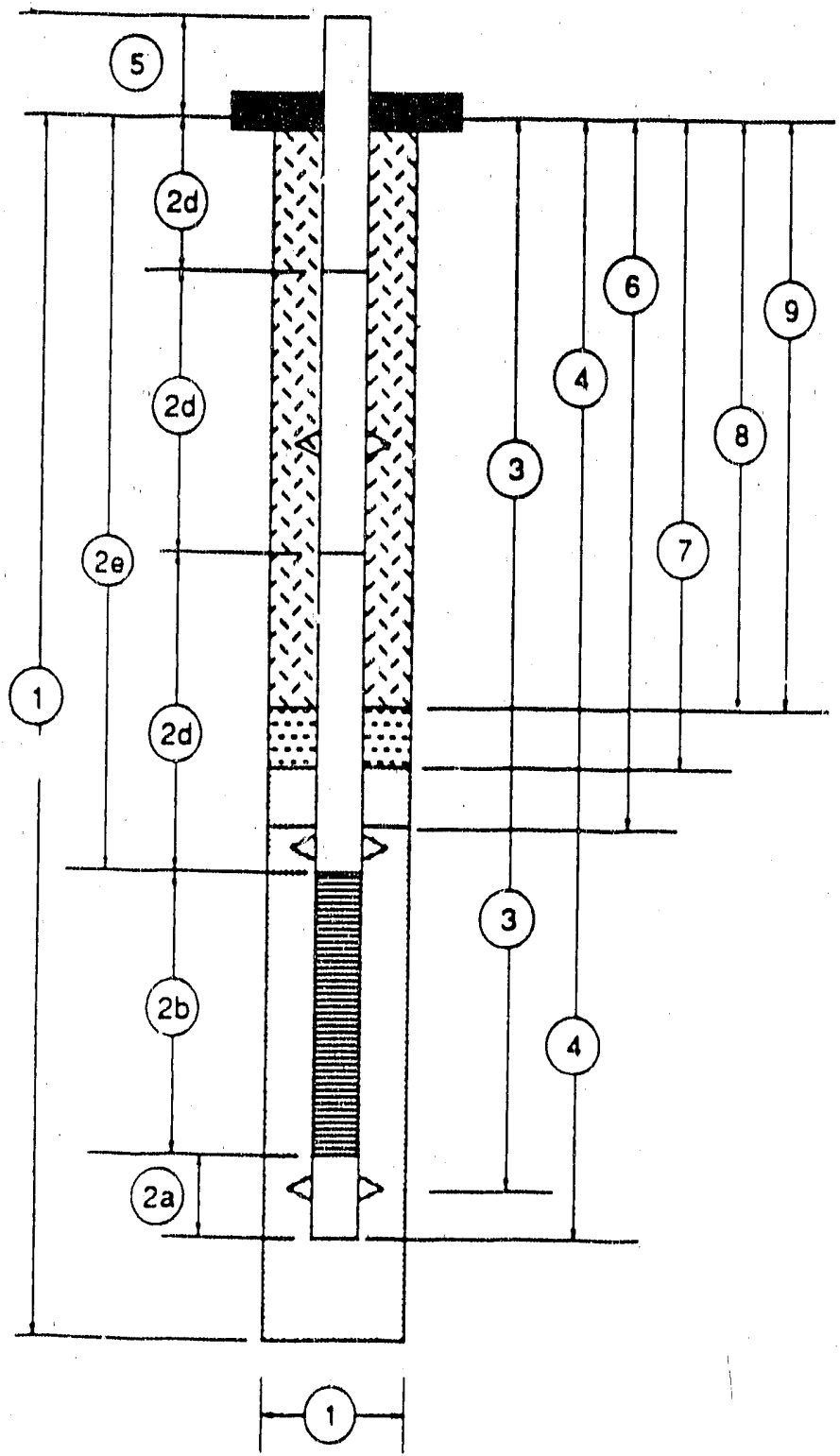

NOTE: ALL MEASURESIENTS

ARE FROM GROUND

SURFACE AT START

OF BORING - MEASUREMENTS

TO NEAREST 0.1 FOOT.

\begin{aligned} & WELL NUMBER AMB-11D \\ & \cline { 2 - 2 } N 103132.29 \\ & SAP COORDINATES E 51932.57 \\ & \hline\end{aligned}

SANITARY SEAL ELEVATION

364.03

1) Total drilled depth/hole diameler $150.0 \mathrm{Ht.} / 117 / 8 \mathrm{ln}$.

2) Casing/Screon Tally (Measured to Nearest 0.01 Foot) $149.36 \mathrm{H}$.
(a) Sump \& Plug
$5.38 \mathrm{H}$.

(b) Screen Length

$19.98 \mathrm{ft}$.

(c) Screen Type/Slot Size

Sch. 40 PVC/0.015 In.

(d) Casing Joint Lengths (Measured in uphole Sequence from Top of Screen) $10.03 / 10.02 / 10.03 /$ $10.02 / 10.02 / 10.02 / 10.03 / 10.02 / 10.01 / 10.01 / 10.01 / 10.00 /$ 3.78

(e) Total Length of Casirig_ $\quad 124.0 \mathrm{ft}$.

(f) Typo of Casing Sch. 40 PVC, 4 In. dlameter

3) Depths to Contralizers $20 / 40 / 80 / 120 / 142$

4) Total Depth of Installed Well $\quad \mathbf{1 4 6 . 8 6} \mathrm{H}$.

5) Casing Stick Up (Standard 2.5' A.G.S) $2.50 \mathrm{ft}$.

6) Depth to Top of Filter Pack $\quad 115.4$ H.

$\begin{array}{lll}\text { Quantity (BagsL } & 23 & \text { Size FX.50 } \\ \text { Brand/Trade Nama } & \text { Foster-DIxlana }\end{array}$

7) Depth to Top of Fine Sand Seal $112.8 \mathrm{H}$.

Quantity (Sacks) 2

8) Depth to Top of Bentonite Seal $108.0 \mathrm{H}$.

Quantity (Buckets) 3

9) Thickness of Grout $108.0 \%$

Total Grout Quantity (Bags) $8 / 54$ 
DRILLING SUBCONTRACTOR

Graves

IILLER Jim Hall/\#653 (SC)

DATE OF INSTALLATION $\quad 6 / 15 / 89$ TECH. O.S./CO.NAME R.J. Hunt/SIrrine

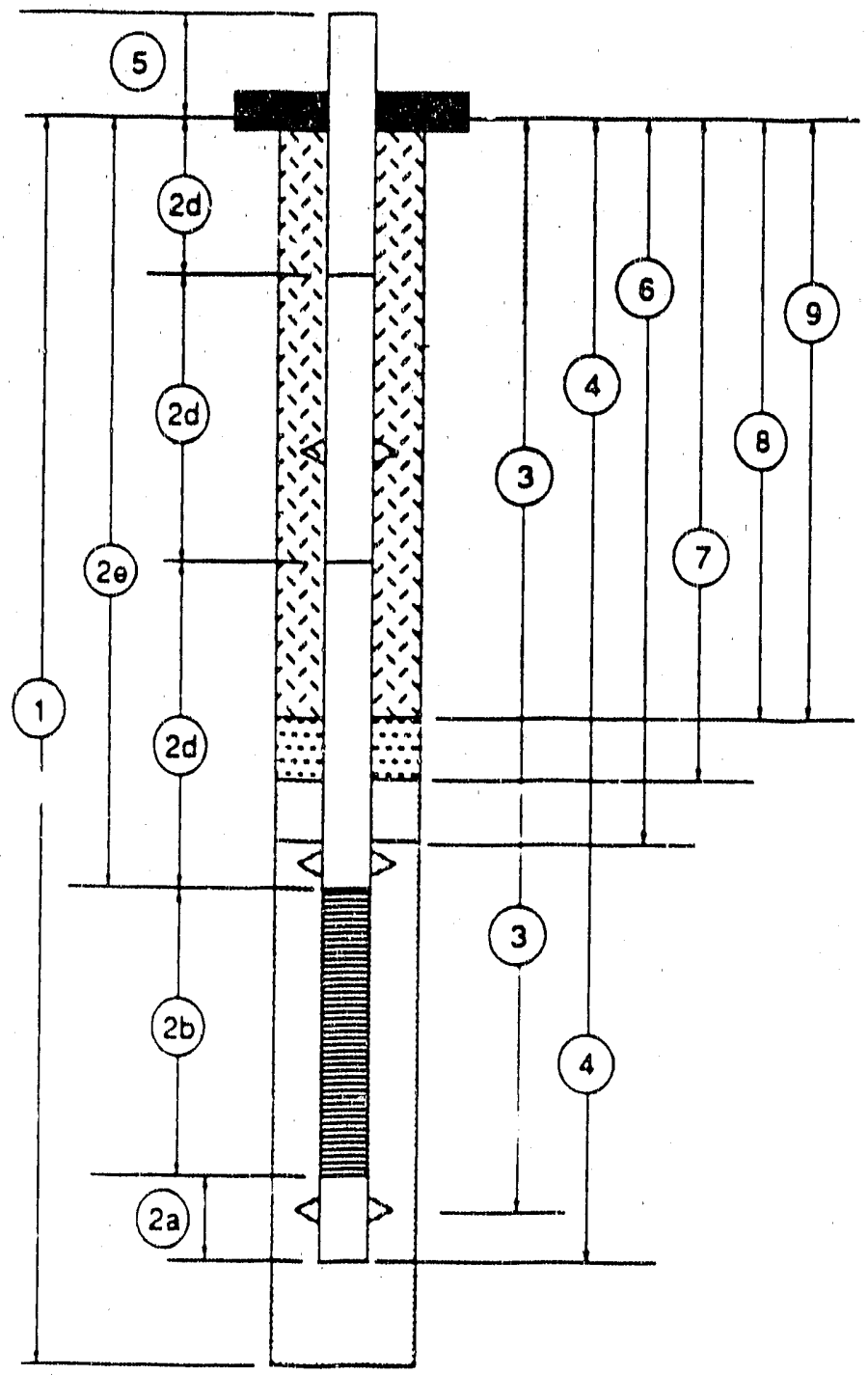

4) Total drilled depth/hole diameter

$159.1 \mathrm{H} . / 117 / 8 \mathrm{In}$.

2) Casing/Screen Tally (Measured to Nearest 0.01 Foot) $156.31 \mathrm{ft}$.

(a) Sump \& Plug $5.38 \mathrm{ft}$.

(b) Screen Length

$20.04 \mathrm{ft}$.

(c) Scroen Type/Slot Size Sch. 40 PVC/0.015 In.

(d) Casing Joint Longths (Measured in uphole sequence from Top of Screeni $10.01 / 10.01 / 10.01 /$ $10.01 / 10.01 / 10.01 / 10.02 / 10.01 / 10.01 / 10.02 / 10.02 / 10.01 /$ $10.02 / 0.72$

(ब) Total Length of Casing _ $\quad 130.89 \mathrm{H}$.

(i) Type of Casina Sch. 40 PVC, 4 In. dlameter

3) Depths to Centralizers $47 / 87 / 127 / 149$

4) Total Depth of Installed Well_ $153.81 \mathrm{ft}$.

5) Casing Stick Up (Standard 2.5' A.G.S)

$2.50 \mathrm{ft}$.

6) Depth to Top of Fither Fack $122.54 \mathrm{th}$.

Quantity (BagsL $\quad 19 \quad$ Size FX.50

Brand/Trade Name___ Fosier.DIxlana

7) Depth to Top of Fine Sand Seal $118.56 \mathrm{tt}$.

Quantity (Sacks) 2

NOTE: ALL MEASUREMENTS ARE FROM GROUND SURFACE AT START OF BORING - MEASUREMENTS TO NEAREST 0.1 FOOT.

8) Depth to Top of Bentonite Seal $115.65 \mathrm{t}$.

Quantity (Buckots) 3

- Fine sand to $113.41 \mathrm{tt}$.

9) Thickness of Grout $183.41 \mathrm{H}$. $6 / 48$ 

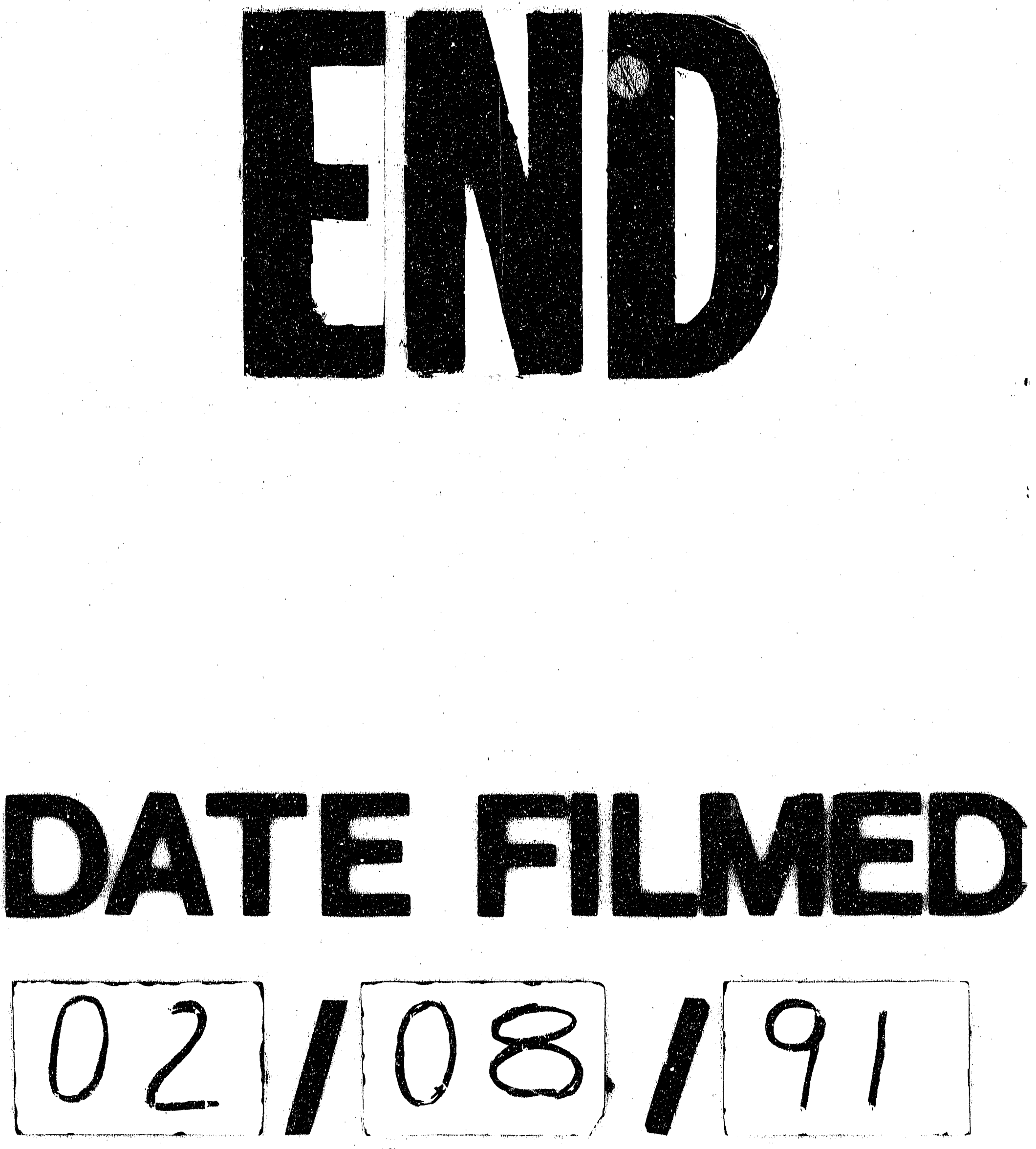
